\title{
Procalcitonin as a diagnostic marker for sepsis - a systematic review and meta-analysis
}

\author{
Dissertation \\ zur Erlangung des akademischen Grades
}

doctor medicinae (Dr. med.)

vorgelegt dem Rat der Medizinischen Fakultät der Friedrich-Schiller-Universität Jena

von Christina Wacker

geboren am 23.06.1987 in Bad Salzungen 


\section{Gutachter}

1. Prof. Dr. Peter Schlattmann, Jena

2. Prof. Dr. André Scherag, Jena

3. PD Dr. Didier Keh, Berlin

Tag der öffentlichen Verteidigung: $\quad \mathbf{0 7 . 0 6 . 2 0 1 6}$ 


\section{Abkürzungsverzeichnis}

AUC

CI

CRP

ED

e.g.

et al.

FN

FP

HW

HWZ

ICU

IL-6

IQR

LBP

LPS

MOV

$\mathrm{n}$

PAMPs

PCT

PICU

PLAUR

PRR

QUADAS
Area under the curve/ Fläche unter der Kurve

Confidence interval/ Konfidenzintervall

C-reaktives Protein

Emergency department

Exempli gratia (zum Beispiel)

Et alii (und andere)

False negative/ Falsch negativ

False positive/ Falsch positiv

Hospital ward

Halbwertszeit

Intensive care unit

Interleukin-6

Interquartile range/ Interquartilsabstand

Lipopolysaccharid bindendes Protein

Lipopolysaccharid

Multiorganversagen

Anzahl

Pathogen associated molecular patterns

Procalcitonin (ng/mL)

Paediatric intensive care unit

Plasminogen activator urokinase receptor

Pattern recognition receptor

Quality Assessment of Diagnostic Accuracy Studies 
Area under the receiver operating characteristic curve/ Fläche unter der Grenzwertoptimierungskurve

SIRS

Systemic inflammatory response syndrome/ Systemisches inflammatorisches Response-Syndrom

SROC

Summery receiver operating characteristic

STARD

Standards for the reporting of diagnostic accuracy studies

TLR

Toll-like-Rezeptor

TN

True negative/ Richtig negativ

TNF- $\alpha$

$\mathrm{TP}$

Tumornekrosefaktor- $\alpha$

True positive/ Richtig positiv

TREM1

Triggering receptor expressed on myeloid cells 1 


\section{Inhaltsverzeichnis}

Abkürzungsverzeichnis........................................................II

Inhaltsverzeichnis...................................................................

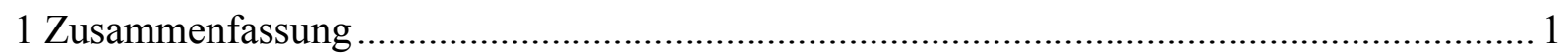

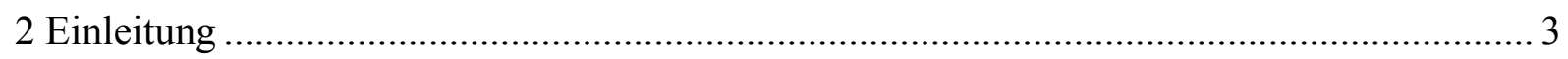

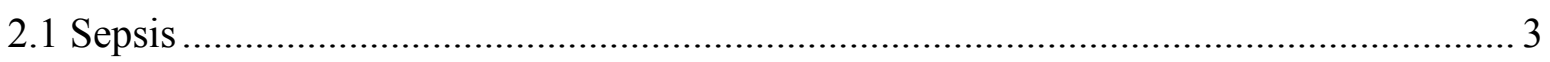

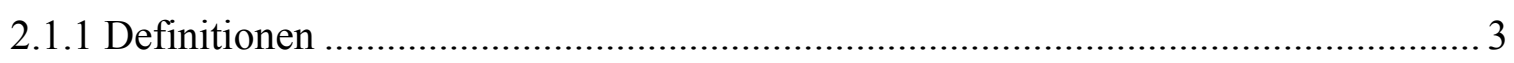

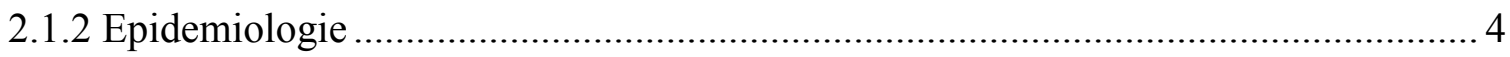

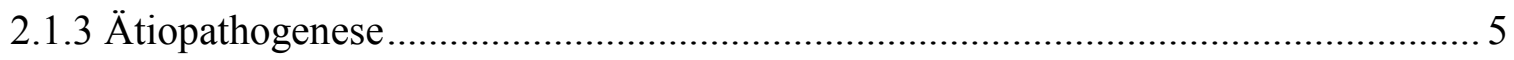

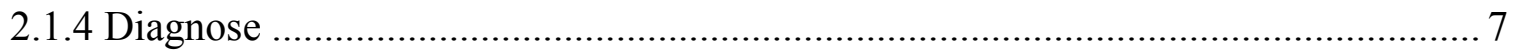

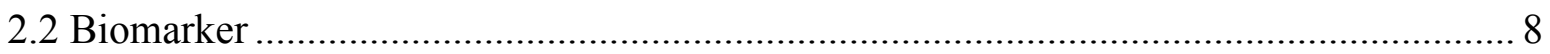

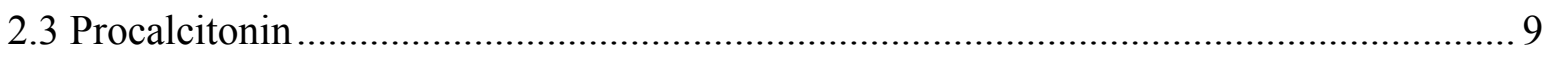

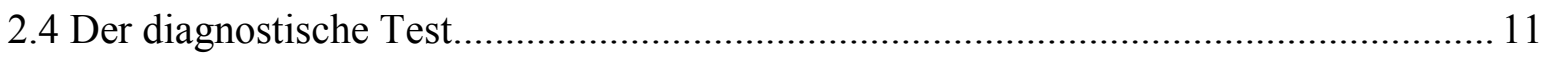

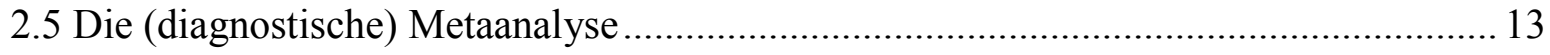

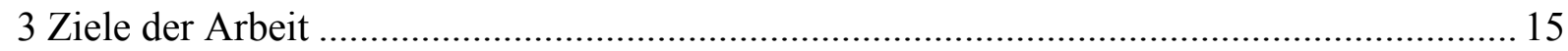

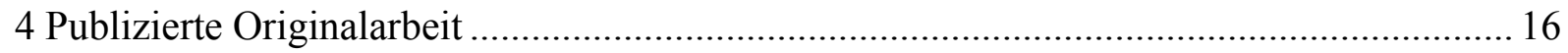

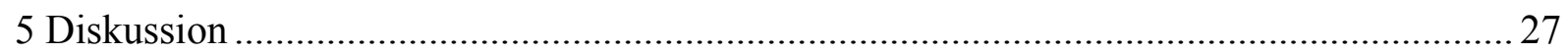

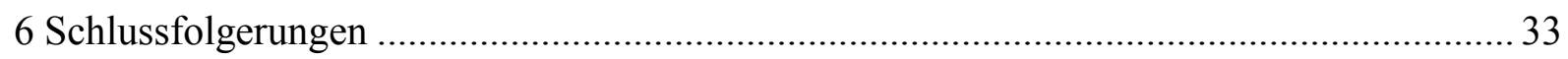

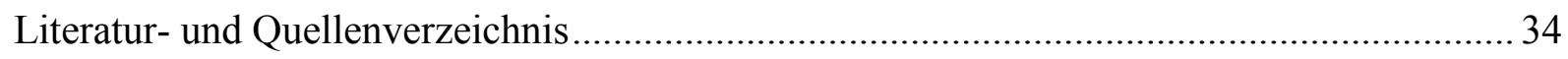

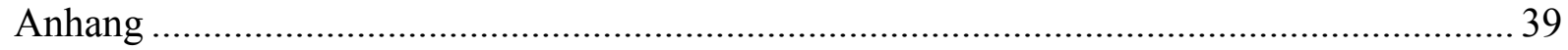

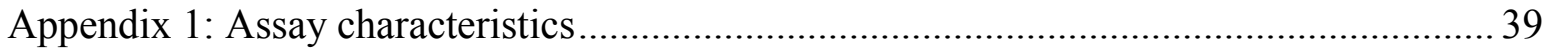

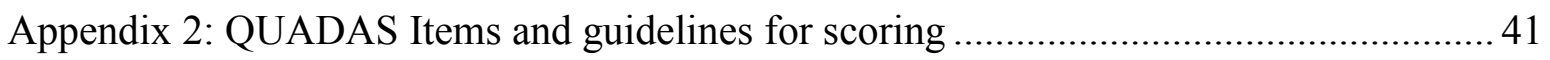

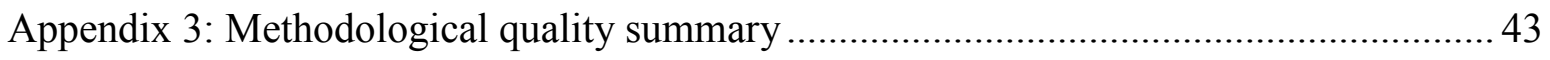

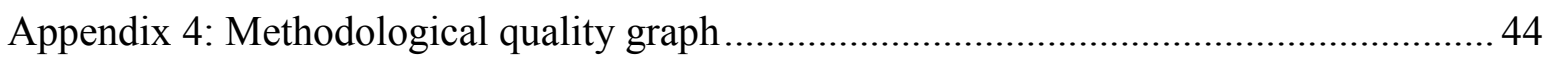

Appendix 5: STARD checklist for reporting of studies of diagnostic accuracy ................ 45

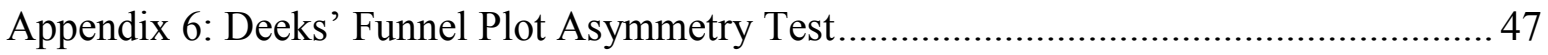

Lebenslauf Fehler! Textmarke nicht definiert.

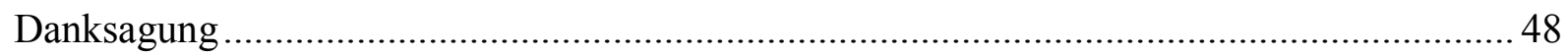

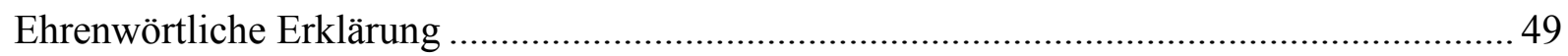




\section{Zusammenfassung}

Hintergrund/Ziele: Sepsis und ihre unmittelbaren Folgen stellen weltweit auch heute noch, sowohl bei Patienten mit ambulant erworbenen als auch bei Patienten mit nosokomialen Infektionen, einen häufigen Grund für Krankheit und Tod dar. Erste klinische Zeichen der Sepsis, wie z.B. Fieber, Tachykardie und Leukozytose, sind unspezifisch und decken sich häufig mit Symptomen eines systemischen inflammatorischen Response-Syndroms (SIRS) nicht bakterieller Genese. Während der Immunantwort des Körpers auf eine Infektion wird eine Vielzahl von Entzündungsmediatoren freigesetzt. Zahlreiche dieser Mediatoren wurden auf ihre Fähigkeit hin untersucht, eine Sepsis zu diagnostizieren, den Schweregrad abzuschätzen bzw. die Prognose vorherzusagen. Als vielversprechendster Biomarker zeigte sich jedoch das 116 Aminosäuren lange Prohormon des Calcitonins, das Procalcitonin. Dieses bietet einige Vorteile gegenüber anderen potentiellen Biomarkern, z.B. einem schnellen Anstieg im Blut nach bakteriellem Stimulus sowie eine lange Halbwertszeit.

Ziel dieser Arbeit war es, die diagnostische Wertigkeit von Procalcitonin bei kritisch kranken Patienten mit Sepsis zu ermitteln und anhand dieser, eine Schlussfolgerung über dessen Nutzen im klinischen Alltag zu ziehen.

Methodik: Es wurden die Datenbanken Medline, Embase, ISI Web of Knowledge, the Cochrane Library, Scopus, BioMed Central und Science Direct von deren Entstehung an bis zum 21.02.2012 nach Studien durchsucht, die die Fähigkeit des Procalcitonins eruieren, zwischen septischen Patienten - also solchen mit Sepsis, schwerer Sepsis und septischem Schock - und Patienten mit SIRS nicht bakterieller Genese zu unterscheiden. Es wurden nur Primärstudien eingeschlossen, die in englischer, deutscher oder französischer Sprache verfasst wurden. Zwei voneinander unabhängige Untersucher extrahierten Patienten- und Studiencharakteristiken und führten diese tabellarisch auf. Unstimmigkeiten wurden in Absprache untereinander oder, bei weiterer Uneinigkeit, mit einem dritten Untersucher geklärt. Weiterhin wurden sowohl Sensitivität und Spezifität für die Einzelstudien als auch die Gesamtsensitivität bzw. -spezifität aller Studien berechnet. Um die Arbeit auf Heterogenität hin zu untersuchen, wurde der $\mathrm{I}^{2}$ genutzt. Des Weiteren wurde eine Meta-Regression durchgeführt, um die Ursache der Heterogenität zu identifizieren.

Ergebnisse/Diskussion: Mittels Literaturrecherche in den Datenbanken konnten insgesamt 3487 relevante Studien identifiziert werden, wovon 30 den Einschlusskriterien entsprachen. Insgesamt wurden Daten von 3244 Patienten verwertet. In der durchgeführten bivariaten Analyse wurde eine Gesamtsensitivität von $0,77 \quad(95 \%$ CI $0,72-0,81)$ und eine 
Gesamtspezifität von $0,79(95 \%$ CI $0,74-0,84)$ ermittelt. Die Area under the revceiver operating characteristic curve (ROC AUC) betrug 0,85 (95\% CI 0,81-0,88). Zwischen den Studien wurde eine erhebliche Heterogenität ( $\mathrm{I}^{2}=96 \%$, 95\% CI 94-99) festgestellt. Keine der durch Meta-Regression untersuchten Studiencharakteristiken, wie Population, Aufnahmemodus, Procalcitonin-Test, Schwere der Erkrankung sowie Beschreibung und Verblindung des Referenzstandards, konnte für die gefundene Heterogenität verantwortlich gemacht werden. Zwischen den Studien variierten des Weiteren die Schwellenwerte stark. Um auch dies als Grund für die gefundene Heterogenität auszuschließen, wurde anschließend der Tresholdeffekt untersucht. Dieser gibt an, welcher Anteil an der Heterogenität sich durch Variabilität im Schwellenwert erklären lässt. Mit 0,05 ist dieser eher klein.

Weiterhin ließ sich in dieser Arbeit ein Publikationsbias finden (18,57). Studien mit positiven Ergebnissen haben im Allgemeinen eine bessere Chance publiziert zu werden als Studien mit negativen Ergebnissen. Dies könnte unter Umständen zur Überschätzung des Gesamteffektes führen. Um dies $\mathrm{zu}$ vermeiden, wurden sowohl die Datenbanken als auch die Literaturverzeichnisse der Primärstudien ein weiteres Mal untersucht, mit dem Ziel weitere potenzielle Studien zu identifizieren.

Schlussfolgerung: Procalcitonin ist ein hilfreicher Marker für die frühzeitige Diagnose der Sepsis bei kritisch kranken Patienten. Nichtsdestotrotz sollte es nicht uneingeschränkt als alleiniger und endgültiger Test verwendet werden, sondern immer in Zusammenhang mit Anamnese, klinischer Untersuchung und, wenn möglich, mit mikrobiologischen Ergebnissen interpretiert werden. Weiterhin empfiehlt sich die kontinuierliche Re-Evaluierung während des gesamten Verlaufes der Erkrankung. 


\section{Einleitung}

\subsection{Sepsis}

\subsubsection{Definitionen}

Sepsis ist eine komplexe systemische inflammatorische Reaktion des Körpers auf eine Infektion. Im August 1991 wurde in Northbrook die American College of Chest Physicians/ Society of Critical Care Medicine Consensus Konferenz abgehalten (Bone et al. 2009), mit dem Ziel einheitliche Definitionen für den Zustand der Sepsis zu schaffen. Erste klinische Zeichen der Sepsis, wie z.B. Fieber, Tachykardie und Leukozytose, sind unspezifisch und decken sich häufig mit Symptomen, die auch im Rahmen einer systemischen inflammatorischen Reaktion des Körpers nicht bakterieller Genese auftreten können. Um möglichst frühzeitig eine adäquate Therapie beginnen zu können, ist es essentiell wichtig, zwischen einer Sepsis einerseits und einem sog. systemischen inflammatorischen ResponseSyndrom (SIRS) andererseits zu unterscheiden.

Das systemische inflammatorische Response-Syndrom kann bei einer Vielzahl von klinischen Ereignissen, wie z.B. Trauma, Verbrennungen, Pankreatitis usw., beobachtet werden. Es geht nicht obligat mit einer Infektion durch Bakterien, Pilze oder Parasiten einher. Um die Diagnose eines SIRS stellen zu können, müssen jedoch mindestens zwei der folgenden Kriterien erfüllt sein (Bone et al. 2009):

(1) Temperatur $\geq 38^{\circ} \mathrm{C}$ oder $\leq 36^{\circ} \mathrm{C}$

(2) Tachykardie mit einer Herzfrequenz $\geq 90 / \mathrm{min}$

(3) Tachypnoe mit einer Frequenz $\geq 20 /$ min oder Hyperventilation mit $\mathrm{PaCO} 2 \leq 4.3 \mathrm{kPa} /$ $\leq 33 \mathrm{mmHg}$

(4) Leukozytose $(\geq 12000 / \mathrm{mm} 3)$ oder Leukopenie $(\leq 4000 / \mathrm{mm} 3)$ oder $\geq 10 \%$ unreife Neutrophile im Differentialblutbild

Liegt eine Infektion in Zusammenhang mit mindestens zwei der oben genannten SIRSKriterien vor, spricht man von einer Sepsis. Kommt es zudem zu einer akuten Organdysfunktion, besteht eine schwere Sepsis. Ein septischer Schock, als schwerwiegendstes Ausmaß einer Sepsis, liegt vor, wenn mindestens zwei SIRS-Kriterien erfüllt sind, eine Infektion vorliegt und für wenigstens 1 Stunde trotz adäquater Volumensubstitution ein systolischer arterieller Blutdruck von $\leq 90 \mathrm{mmHg}$ bzw. ein mittlerer arterieller Blutdruck von $\leq 65 \mathrm{mmHg}$ gemessen wird oder wenn ein Vasopressoreinsatz notwendig ist, um den 
systolischen arteriellen Blutdruck $\geq 90 \mathrm{mmHg}$ oder den arteriellen Mitteldruck $\geq 65 \mathrm{mmHg} \mathrm{zu}$ halten (Reinhart et al. 2010).

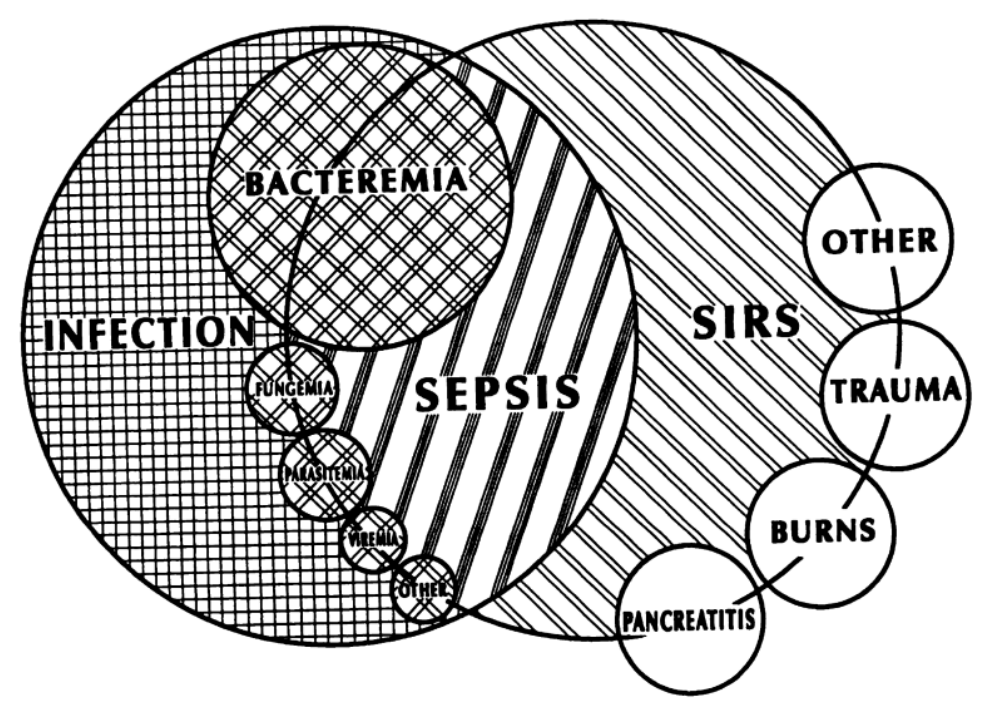

Abbildung 2.1.1 Beziehungen zwischen dem systemischen inflammatorischen Response-Syndrome (SIRS), Infektion und Sepsis (Bone et al. 2009)

\subsubsection{Epidemiologie}

Sepsis und ihre unmittelbaren Folgen stellen weltweit auch heute noch, sowohl bei Patienten mit ambulant erworbenen als auch bei Patienten mit nosokomialen Infektionen, einen häufigen Grund für Krankheit und Tod dar (Angus et al. 2001, Engel et al. 2007, Martin et al. 2003). Allein in Deutschland erkranken ca. 220 Menschen pro 100.000 Einwohner und Jahr an einer Sepsis. Die Krankenhaussterblichkeit liegt bei ca. 54\%. Mit 60.000 Todesfällen im Jahr stellen septische Erkrankungen somit die dritthäufigste Todesursache hierzulande dar (Engel et al. 2007). Die Wahrscheinlichkeit an einer Sepsis zu erkranken ist für Männer pro Jahr gesehen höher als für Frauen (Relatives Risiko: 1,28) (Martin et al. 2003). Die Mehrheit der Patienten ist älter als 60 Jahre (68\%). Nur 7\% der Patienten stammten aus der Altersgruppe zwischen 18 und 39 Jahren. Und 25\% der an Sepsis Erkrankten sind 40-59 Jahre alt. Nichtsdestotrotz versterben in den Gruppen der 18-39 jährigen und 40-59 jährigen Patienten jeweils 46\%, gegenüber 60\% in der Gruppe der über 60-järigen (Brunkhorst 2006). Die direkten intensivmedizinischen Behandlungskosten von Patienten mit einer schweren Sepsis belaufen sich im Jahr auf rund 1,7 Milliarden Euro (Brunkhorst 2006).

Wichtig, um den stationären Aufenthalt zu verkürzen sowie Mortalität und Krankenhauskosten zu senken, ist es, frühzeitig die Diagnose zu stellen, um wiederum zeitnah 
mit einer adäquaten Therapie beginnen zu können (Garnacho-Montero et al. 2008, Pittet et al. 1995).

\subsection{3 Ätiopathogenese}

Eine Sepsis ist eine systemische Entzündungsreaktion des Körpers auf eine Infektion mit Bakterien, deren Toxinen oder Pilzen. Gramnegative Erreger, allen voran Enterobacteriaceae, spielen dabei etwa gleich häufig eine Rolle wie grampositive Erreger, meist Pneumokokken, Staphylokokken und Enterokokken (Bernard et al. 2001). Den häufigsten Krankheitsfokus stellen Atemwegsinfektionen gefolgt von intraabdominalen Infektionen dar (Bernard et al. 2001, Engel et al. 2007, Martin et al. 2003).

Die in den Körper eingedrungenen Pathogene führen über einen komplexen Weg zu einer systemischen Wirtsantwort. Diese verursacht wiederrum Schäden an infektionsortfernen Organen. Im schlimmsten Fall entwickelt sich ein MOV.

Pathogene besitzen erregerassoziierte Liganden, sog. „pathogen-associated molecular patterns“ (PAMPs) (Cohen 2002). Dies können z.B. bakterielle Membranbestandteile, Exotoxine oder bakterielle DNS sein (Bauer et al. 2006). Bei gramnegativen Bakterien spielt das in der äußeren Membran vorhandene Lipopolysaccharid (LPS) eine große Rolle (Villar et al. 2004). Dieses bildet wiederum einen Komplex mit dem LPS bindendem Protein (LBP). Der so entstandene LPS-LBP-Komplex wird nun durch Zellen der unspezifischen Immunabwehr erkannt. Sie besitzen, komplementär zu den PAMPs, ,pattern recognition receptors“ (PRR), wobei hier dem „Toll-like-Rezeptor“ (TLR) eine zentrale Rolle zukommt. So kann der TLR4 direkt oder nach Bindung des LPS-LPB-Komplexes an dem CD14Rezeptor die Wirkung bakterieller Toxine vermitteln (Abbildung 2.1.3). Intrazellulär kommt es so zur Auslösung einer Signaltransduktionskaskade. Hierbei werden Kinasen aktiviert, was wiederum zur Phosphorylierung einer inhibitorischen Untereinheit des Transkriptionsfaktors nukleärer Faktor $\kappa \mathrm{B}$ führt. Dies hat die Genexpression proinflammatorischer Zytokine wie TNF- $\alpha$ und IL-1 zur Folge (Bauer et al. 2006, Villar et al. 2004). Die Ähnlichkeit, der durch verschiedene Pathogene ausgelösten Aktivierungsmuster, erklärt auch die relativ stereotype Wirtsantwort in Form des SIRS. Über Signaltransduktionskaskaden, die durch andere PAMPs bzw. PRRs als LPS bzw. TLR ausgelöst werden, ist bisher nur wenig bekannt (Bauer et al. 2006). 


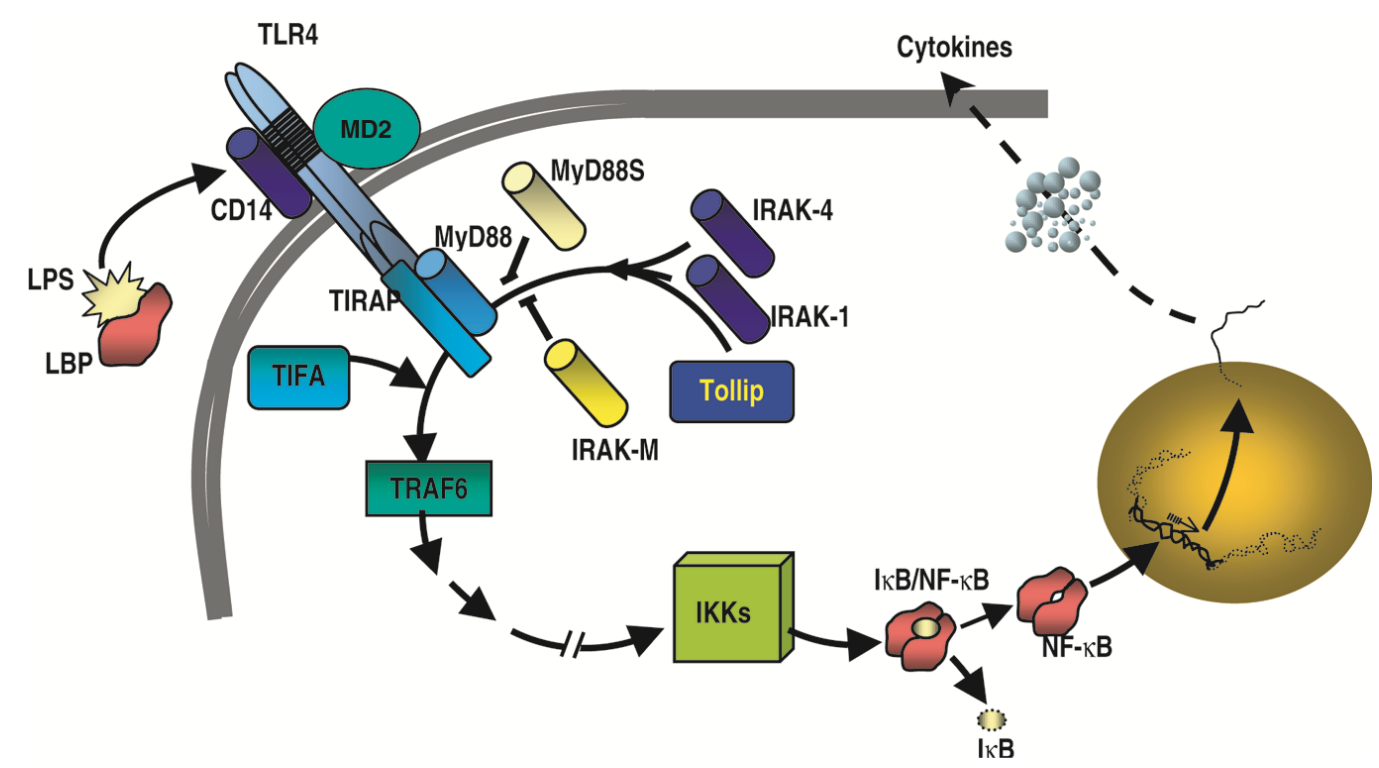

Abbildung 2.1.3 Registrierung eines eingedrungenen Pathogens durch den TLR4 auf der Oberfläche eines Makrophagen und dadurch ausgelöste intrazelluläre Signaltransduktionskaskade (Villar et al. 2004)

Die Ausschüttung von frühen proinflammatorischen Zytokinen wie TNF- $\alpha$ oder IL-1 durch Monozyten bzw. Makrophagen zieht nun weitere Schritte nach sich. Zum einen wirken diese Zytokine in höherer Konzentration selbst direkt gewebeschädigend. Zum anderen stimulieren sie andere an der akuten Entzündungsreaktion beteiligte Zellen zur Produktion von weiteren Zytokinen und Mediatoren, wie z.B. Chemokinen, Proteasen, Leukotrienen etc. Durch diesen „cross talk“ zwischen den verschiedenen immunkompetenten Zellen kommt es im weiteren Verlauf zu einer massiven Produktion von gewebetoxischen Substanzen. Die Schädigung der Endothel- und Organzellen wird auf verschiedenen Wegen verursacht. So führen zytotoxische Mediatoren, wie z.B. Proteasen und NO, direkt zu einer Schädigung. Bakterielle Endotoxine wirken außerdem direkt auf den Sauerstoffstoffwechsel der Zelle und führen zur Bildung von freien Sauerstoffradikalen, welche wiederum ebenfalls einen toxischen Effekt auf die Zelle haben. Des Weiteren haben die freigesetzten Mediatoren multiple Wirkungen auf verschiedenste Kaskadensysteme, wie Gerinnungs-, Komplement-, und Kallikrein/KininSystem sowie auch direkt auf die Endorgane. Dies hat eine gestörte Mikro- und Makrozirkulation zur Folge, welche ebenfalls $\mathrm{zu}$ funktionellen und strukturellen Schädigungen der Zelle führt. Endstrecke aller genannten Mechanismen ist die hypoxisch induzierte Nekrose betroffener Zellen, welche in einen progredienten Verlust vitaler Zellen mit nachfolgender Organdysfunktion führt (Bauer et al. 2006, Cohen 2002).

Außerdem geht man davon aus, dass neben der überschießenden proinflammatorischen Zytokinantwort auch eine vermehrte Ausschüttung antiinflammatorischer Zytokine, wie IL-4 
und -10, und eine daraus resultierende gleichzeitig bestehende Immunsuppression eine Rolle in der Entstehung des Krankheitsbildes spielen könnte (Chaudhry et al. 2013, Gogos et al. 2000). Die Pathogenese der Sepsis ist insgesamt ein sehr komplexer Vorgang. Sie ist bis heute noch nicht komplett verstanden und weiterhin Objekt zahlreicher Untersuchungen, vor allem auch im Hinblick auf sich daraus ergebende therapeutische Möglichkeiten.

\subsubsection{Diagnose}

Untersuchungen ergaben, dass eine Verzögerung bei der Diagnose der Sepsis mit daraus resultierendem verspäteten Therapiebeginn sowohl den stationären Aufenthalt verlängert als auch Mortalität und Krankenhauskosten signifikant erhöht (Pittet et al. 1995, Rivers et al. 2001). Daher kommt der Diagnostik der Sepsis im klinischen Alltag eine bedeutende Rolle $\mathrm{zu}$.

Die Herausforderung liegt darin, dass es bisher leider noch keinen Parameter gibt, der, für sich allein genommen, eine Sepsis diagnostizieren kann. Vielmehr handelt es sich um eine Kombination aus verschiedenen Vitalparametern, Laborwerten und Organdysfunktionen, die zwar meist sehr sensitiv, jedoch wenig spezifisch ist und sich in der Regel nicht von Symptomen einer nicht-infektiösen Entzündungsreaktion unterscheidet (Bauer et al. 2006).

Laut den Diagnosekriterien der ACCP/ACCM Konsensus-Konferenz liegt eine Sepsis dann vor, wenn mindestens zwei der oben genannten Kriterien der SIRS erfüllt sind und die Infektion mikrobiologisch und/oder klinisch nachgewiesen wurde (Bone et al. 2009).

Zur Erregerdiagnostik werden im klinischen Alltag regelmäßig Blutkulturen abgenommen. Diese sind jedoch in Abhängigkeit von der antibiotischen Vorbehandlung nur in ca. $30 \%$ der Fälle positiv und daher nur begrenzt verwertbar (Bates et al. 1990, Bates et al. 1997). Auch die Interpretation anderer mikrobiologischer Untersuchungen, wie z.B. von Wundabstrichen, ist problematisch, da eine Unterscheidung zwischen Kolonisation und Infektion oft nicht gelingt (Bauer et al. 2006). Ebenso schwierig gestaltet sich der klinische Nachweis der Infektion. Durch die fehlende Standardisierung der klinischen und radiologischen Untersuchungen kommt es häufig zu einer Variabilität der Ergebnisse zwischen verschiedenen Untersuchern.

Am vielversprechendsten für die Diagnose der Sepsis zeigte sich in den letzten Jahren die Patientendiagnostik mittels geeigneter Biomarker. Während der akuten Entzündungsreaktion werden eine Vielzahl von Zytokinen und weiteren Mediatoren ausgeschüttet, die sich im Verlauf in der Blutbahn nachweisen lassen und die sich mehr oder weniger gut zur Diagnose 
der Sepsis eignen. Am aussichtsreichsten zeigte sich das 116 Aminosäuren lange Prohormon des Calcitonins, das Procalcitonin. Dieses bietet einige Vorteile gegenüber anderen potentiellen Biomarkern, z.B. einem schnellen Anstieg im Blut nach bakteriellem Stimulus sowie eine lange Halbwertszeit.

\subsection{Biomarker}

Biomarker stellen objektiv messbare biologische Merkmale bzw. Produkte dar, die entweder in einem Organismus vorhanden sind oder aber während verschiedener Stoffwechselvorgänge gebildet werden. Dies können z.B. Zellen, Gene, Genprodukte, Hormone, Enzyme etc. sowohl mit als auch ohne biologische Aktivität sein. In der Medizin wird auf verschiedenen Wegen Nutzen aus ihnen gezogen. Zum einen können sie zum Screening verwendet werden. So werden Patienten, die ein erhöhtes Risiko haben, an einem bestimmten Leiden zu erkranken, identifiziert. Daraufhin können weitere diagnostischen Tests durchgeführt werden bzw. prophylaktische Maßnahmen eingeleitet werden. Zum anderen kann aber auch eine Diagnose mit Hilfe von Biomarkern gestellt werden, was wiederum den Gewinn hat, dass dem Patienten schneller eine adäquate Therapie zugutekommen kann. Des Weiteren eignen sie sich zur Stratifikation. Patienten, die von einer bestimmten Behandlung einen größeren Nutzen als andere davontragen, können hierbei identifiziert werden. Außerdem können sich Biomarker sehr gut als Indikator des Therapieerfolges eignen und somit wegweisend für das weitere therapeutische Vorgehen sein. Zum Schluss ist noch die Funktion als Vorhersagewert für das Outcome eines Patienten zu nennen (Marshall und Reinhart 2009).

Nicht alle Biomarker eignen sich aufgrund unterschiedlicher Eigenschaften und verschiedenartigen Verhaltens gleich gut für jede dieser Funktionen. So werden an einen diagnostischen Biomarker bestimmte Anforderungen gestellt. Bezogen auf die Sepsis, bei der es wie oben genannt noch keinen eindeutigen Goldstandard für die Diagnosestellung gibt, bedeutet dies, dass einerseits mit seiner Hilfe die Zeit verkürzt werden sollte, die benötigt wird, um eine eindeutige Diagnose $\mathrm{zu}$ stellen. Hierzu gehört leicht zugängliches Probenmaterial sowie auch ein schnelles und eindeutiges Testergebnis. Andererseits sollte solch ein Marker in der Lage sein, ein Problem zu lösen, welches in der Vergangenheit die sichere Diagnose der Sepsis so erschwert hat: nämlich zwischen einer systemischen Entzündungsreaktion bakterieller Genese von einer solchen nicht-bakterieller Genese eindeutig zu unterscheiden (Reinhart et al. 2006). 
Wie oben erwähnt, werden während der akuten Inflammation eine Vielzahl von Zytokinen und weiteren Mediatoren ausgeschüttet, die sich im Verlauf in der Blutbahn nachweisen lassen. Viele dieser potentiellen Biomarker standen in den letzten Jahren im Fokus der Forschung, um deren Nutzen als diagnostischen Marker bei der Sepsis zu eruieren.

\subsection{Procalcitonin}

Als erfolgversprechendster Biomarker, was die Diagnose der Sepsis angeht, zeigte sich bisher das 116 Aminosäure lange Prohormon des Calcitonins, das Procalcitonin.

Calcitonin ist ein Peptidhormon, welches den Calcium- und Phosphathaushalt des Körpers reguliert und somit, ebenso wie Parathormon und Calcitriol, Einfluss auf den Knochenstoffwechsel hat. Es wird vor allem in den C-Zellen der Schilddrüse, aber auch in wenigen neuroendokrinen K-Zellen der Lunge gebildet (Becker et al. 2010, Christ-Crain und Muller 2005).

Das für Procalcitonin (PCT) kodierende Gen heißt, wie auch das für Calcitonin selbst, CALCI-Gen und liegt auf Chromosom 11 (Becker et al. 2010, Meisner 2002, Muller und Becker 2001). Proteine bzw. deren mRNA liegen vorerst typischerweise in der Pro-Pro-Form vor. Erst durch zahlreiche, parallel verlaufende Schritte der Prozessierung entsteht später das fertige Protein. Das CALC-I-Gen ist hierbei ein gutes Beispiel für die Pluripotenz von Genomsequenzen. Aus nur einem Gen können später unterschiedlichste Genprodukte entstehen. Die Proteine unterscheiden sich hierbei nicht nur in Hinsicht auf die Prozessierung, sondern auch in Bezug auf ihre Regulation (Meisner 2002). Während das Calcitonin Teil des normalen Stoffwechsels ist, ist die Produktion seines Prohormons im gesunden Organismus supprimiert. Erst das Eindringen von bakteriellen Toxinen bzw. die Produktion von in diesem Zusammenhang gebildeten Entzündungsmediatoren wirkt als Stimulus, welcher zu einer ubiquitären Expression des Calcitoningens in verschiedenen Körperzellen führt (Muller und Becker 2001). PCT wird daraufhin vor allem von parenchymatösen Organen, wie z.B. der Leber, freigesetzt. Es kann aber prinzipiell von allen differenzierten Zellen der Körpers produziert werden. Während man also beim Calcitonin von einer regulierten Sekretion in Folge eines endokrinen Stimulus spricht, ist die Freisetzung des Procalcitonins auf einen bakteriellen Stimulus hin als konstitutiv, also unreguliert, zu betrachten (Christ-Crain und Muller 2005) (Abbildung 2.3). 


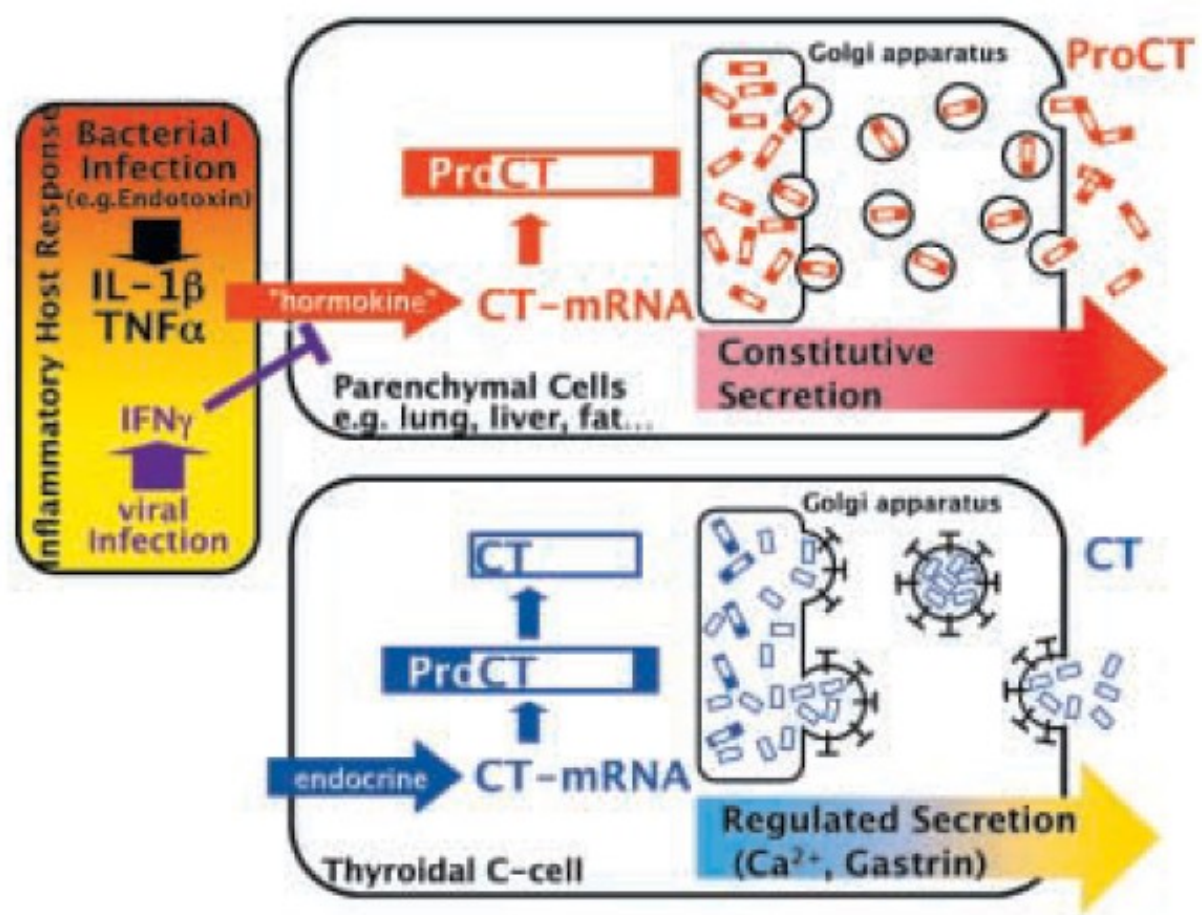

Abbildung 2.3 Schematische Darstellung der unterschiedlichen Expression des CALC-Gens in CZellen der Schilddrüse einerseits und parenchymatösen Zellen andererseits. In den C-Zellen wird durch einen bestimmten endokrinen Stimulus vorerst das 116-aminosäure-lange Procalcitonin synthetisiert. Durch posttranslationale Modifikation entsteht im Folgenden das am Stoffwechsel beteiligte Calcitonin. Man spricht von einer regulierten Sekretion. Im Gegensatz dazu die konstitutive Sekretion von Procalcitonin. Durch bakterielle Toxine sowie durch Entzündungsmediatoren kommt es zur Produktion von PCT. Parenchymatöse Zellen besitzen im Unterschied zu den endokrinen Zellen der Schilddrüse keine sekretorischen Granula, sodass das PCT unreguliert freigesetzt wird (ChristCrain und Muller 2005).

So kann die Konzentration von PCT im Blut im Vergleich zum Gesunden mehrere 1000-fach ansteigen und korreliert oft mit dem Schweregrad der Erkrankung (Assicot et al. 1993, Brunkhorst et al. 2000, Christ-Crain und Muller 2005). Dies und auch der Umstand, dass PCT schon kurze Zeit nach bakteriellem Stimulus ansteigt und gleichzeitig eine lange Halbwertszeit besitzt (Dandona et al. 1994), machen es zu einem ausgezeichneten Marker für die Diagnose der Sepsis.

Ein weiterer Vorteil gegenüber anderen Biomarkern ist, das Gleiches nicht für nichtinfektiöse und virale Geschehen zu gelten scheint. In einigen Untersuchungen konnte nachgewiesen werden, dass PCT-Level bei einem viralen Infekt auf relativ niedrigem Niveau bleiben und sich deutlich von den Werten unterscheiden, die erreicht werden, wenn eine bakterielle Infektion vorliegt (Gendrel et al. 1999, Hatherill et al. 1999). 


\subsection{Der diagnostische Test}

Der diagnostische Test ist ein Hilfsmittel, anhand dessen aufgrund gewisser Parameter entschieden werden kann, ob ein bestimmter Zustand, z.B. Krankheit oder Gesundheit, vorliegt. Im Falle dieser Arbeit wird untersucht, ob PCT dazu geeignet ist, zwischen septischen Patienten und solchen mit einer systemischen Inflammationsreaktion $\mathrm{zu}$ unterscheiden. Die Testgenauigkeit kann mittels dichotomer Merkmale aus einer 2x2 Kontingenztafel errechnet werden (Abbildung 2.4a). In einer solchen werden einerseits die wirklich an Sepsis erkrankten bzw. die SIRS-Patienten, denen gegenüber gestellt, die vom Test als „krank“ bzw. „gesund“ ermittelt werden. Die Sensitivität gibt an, welcher Anteil der erkrankten vom Test auch wirklich als erkrankt erkannt wurden. Dem gegenüber steht die Spezifität, welche ermittelt, wie viele der an SIRS erkrankten, als solche erkannt wurden. Außerdem lassen sich aus solch einer Kontingenztafel auch die Vorhersagewerte des Tests bestimmen. Der positive Vorhersagewert gibt an, wie hoch bei einem positiven Test die Wahrscheinlichkeit ist, dass der untersuchte Pat. auch wirklich Sepsis hat. Dem entsprechend gibt der negative Vorhersagewert an, wie hoch bei negativem Testergebnis die Wahrscheinlichkeit ist, dass keine Sepsis vorliegt.

\begin{tabular}{|c|c|c|c|c|c|}
\hline \multirow{3}{*}{$\begin{array}{l}\text { diagnost. Test } \\
(\mathrm{PCT})\end{array}$} & \multirow[b]{3}{*}{ positiv } & \multicolumn{2}{|l|}{ Goldstandard } & \multirow[b]{3}{*}{$a+b$} & \multirow[b]{3}{*}{$\begin{array}{c}\rightarrow \text { pos. VSW } \\
\mathrm{a} /(\mathrm{a}+\mathrm{b})\end{array}$} \\
\hline & & Sepsis & \multirow{2}{*}{$\frac{\text { SIRS }}{\mathrm{b}}$} & & \\
\hline & & $\bar{a}$ & & & \\
\hline & negativ & $\bar{c}$ & $\bar{d}$ & $\mathrm{c}+\mathrm{d}$ & $\begin{array}{c}\rightarrow \text { neg. VSW } \\
\mathrm{d} /(\mathrm{c}+\mathrm{d})\end{array}$ \\
\hline & & $a+c$ & $\mathrm{~b}+\mathrm{d}$ & $a+b+c+d$ & \\
\hline & & $\begin{array}{c}\rightarrow \text { Sensitivität } \\
\mathrm{a} /(\mathrm{a}+\mathrm{c})\end{array}$ & $\begin{array}{c}\rightarrow \text { Spezifität } \\
\mathrm{d} /(\mathrm{b}+\mathrm{d})\end{array}$ & & \\
\hline
\end{tabular}

Abbildung 2.4a 2x2 Kontingenztafel für PCT als diagnostischen Test zur Unterscheidung zwischen Sepsis und SIRS. Daraus errechenbar: Sensitivität, Spezifität, pos. Vorhersagewert und neg. Vorhersagewert.

Voraussetzung, um solch eine Kontingenztafel $\mathrm{zu}$ erstellen und anhand derer die Testgenauigkeit $\mathrm{zu}$ ermitteln, ist, einen Goldstandard $\mathrm{zu}$ haben, der eine Unterscheidung zwischen Sepsis und SIRS auch garantiert. Dies stellt bis heute ein weitgehend ungelöstes Problem dar, auf welches im Verlauf noch einmal genauer eingegangen wird. 
Ein zweiter Faktor, der Sensitivität und Spezifität eines diagnostischen Tests beeinflusst, ist die Wahl des Cut-off-Wertes. Dies ist ein festgelegter Wert, bis zu welchem ein Mensch als „gesund“ eingestuft wird. Alle Werte die darüber liegen, werden als „krank“ interpretiert. Dies ist natürlich im Bereich sehr hoher oder sehr niedriger Werte eindeutig. Jedoch gibt es auch einen weniger eindeutigen Bereich, in welchem beispielsweise klinisch gesunde Menschen wegen leicht erhöhter Werte als krank eingestuft werden. Je nachdem in welche Richtung man den Cut-off-Wert setzt, umso mehr falsch-negative bzw. falsch-positive Ergebnisse entstehen. Das bedeutet: umso höher man den Cut-off-Wert setzt, desto mehr Menschen werden vom Test als gesund eingestuft - man erhöht also die Spezifität auf Kosten der Sensitivität. Gleiches gilt natürlich auch, wenn man den Cut-off-Wert niedriger ansetzt: Die Sensitivität steigt auf Kosten der Spezifität (Abbildung 2.4b). Bei der Wahl des Cut-offWertes ist also immer zu überlegen, welche Konsequenz sich aus der Festlegung dieses Grenzwertes ergibt. Bei einer fulminant verlaufenden Erkrankung, die einer schnellen Intervention bedarf, wäre es z.B. verheerend, den Wert zu hoch zu setzen und damit einigen Pat. eine adäquate Behandlung zu verwehren.

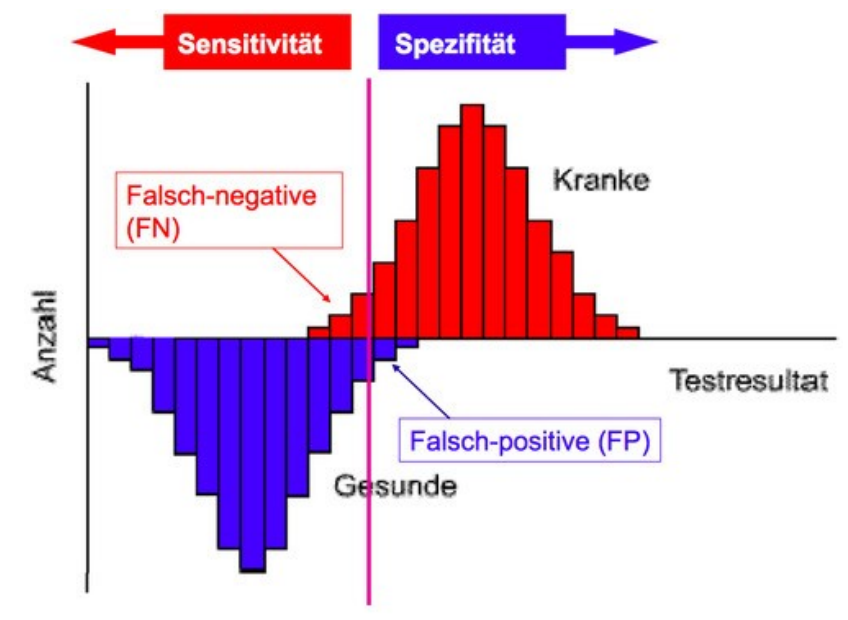

Abbildung 2.4b Darstellung der Sensitivität und Spezifität in Abhängigkeit von der Wahl des CutOff-Wertes (http://quizlet.com/8326507/tb-grundlagen-klinische- chemielabormedizinische-testsflash-cards/, Stand 27.10.2014).

Die Sensitivität und die Spezifität eines Test bei unterschiedlichen Cut-Off-Werten kann auf einer Receiver operating characteristic curve (ROC-curve) abgelesen werden. Der Cut-offWert, der am besten zwischen zwei Zuständen unterscheidet, somit also die höchste Sensitivität und Spezifität aufweist, ist der, welcher sich am nahesten an der linken oberen 
Ecke der Graphik befindet. Der diagnostische Test ist umso besser, je mehr die Form der Kurve der eines Rechtecks entspricht und je näher sie der linken, oberen Ecke der Graphik kommt. Stellt die ROC-curve eine Diagonale dar, ist der Test unbrauchbar (Abbildung 2.4c). Dies lässt sich auch durch die area under the curve (AUC) angeben. Eine AUC von 1 entspricht dem idealen Test. Ein Wert von 0,5 bedeutet Sensitivität $=1$ - Spezifität. Es gibt also ebenso viele richtig positive Ergebnisse wie falsch positive Ergebnisse.

Bevor ein klinischer Test in der Praxis Anwendung findet, sollte mit Hilfe solch einer ROCcurve ein sinnvoller cut-off-Wert zur Unterscheidung zwischen zwei Zuständen gefunden werden.

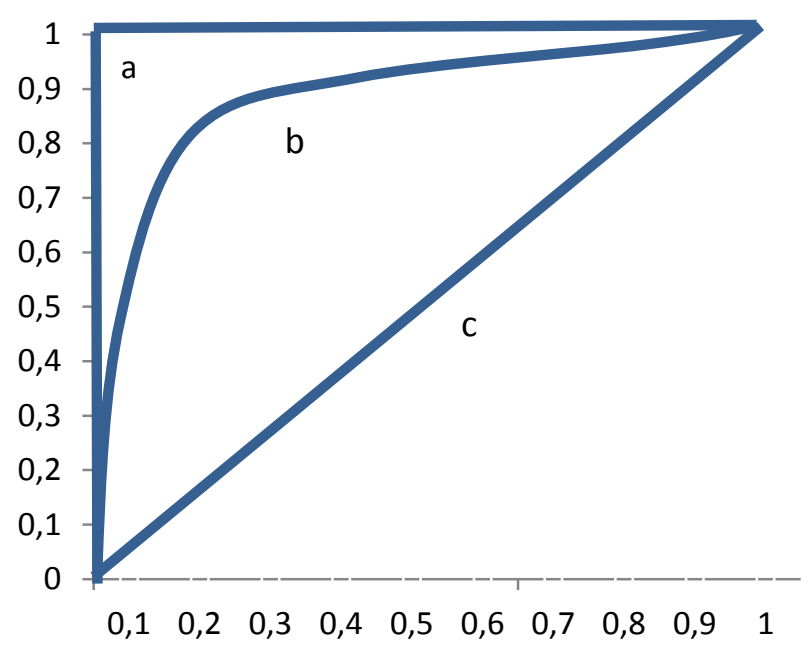

Abbildung 2.4c Receiver operating characteristic curve (ROC-curve). Graph a stellt die Kurve eines idealen Tests dar. Graph $b$ ist eine beispielhafte Kurve, wie sie bei den meisten diagnostischen Tests in etwa aussehen könnte. Graph c entspricht Sensitivität = 1- Spezifität.

\subsection{Die (diagnostische) Metaanalyse}

Eine Metaanalyse ist eine quantitative Zusammenfassung der Ergebnisse verschiedener Primärstudien zu einem Themengebiet. Hieraus ergibt sich durch statistische Berechnungen ein gepoolter Gesamteffekt. Metaanalysen helfen im klinischen Alltag wichtige Entscheidungen zu treffen. Basierend auf randomisierten klinischen Studien entsprechen sie aufgrund der Breite der wissenschaftlichen Basis dem höchsten Evidenzgrad, der Klasse Ia. 
In einem sog. Forest Plot werden die Ergebnisse der Einzelstudien, sowie der gepoolte Gesamteffekt dargestellt. Bei einer diagnostischen Metaanalyse richtet sich die Aufmerksamkeit auf Primärstudien, die die Genauigkeit eines speziellen diagnostischen Tests untersuchen. Diese Genauigkeit, also der diagnostische Nutzen eines Tests, ergibt sich zum einen aus der Sensitivität und zum anderen aus der Spezifität. Um diese beiden Größen nicht miteinander zu vermischen und somit den zweidimensionalen Charakter zu erhalten, sollte die quantitative Datenanalyse durch das von van Houwelingen entwickelte bivariate mixedeffects regression model erfolgen (Van Houwelingen et al. 1993, van Houwelingen et al. 2002). Ähnlich der Einzelstudien kann hiernach eine receiver operating characteristic curve, die SROC-Kurve, mit 95\% Konfidenzellipsoid für den Gesamteffekt ermittelt werden.

Ein Problem einer Metaanalyse ist jedoch, dass die untersuchten Primärstudien häufig Unterschiede bezüglich Größe, untersuchter Population sowie Methoden und Durchführung zeigen und so mitunter sehr unterschiedliche Ergebnisse für die diagnostische Genauigkeit eines Tests erzielen. Bei der quantitativen Datenanalyse sollte deshalb auch eine Untersuchung auf Heterogenität der Primärstudien, z.B. der $\mathrm{I}^{2}$, erfolgen. Hat man eine solche Heterogenität detektiert, sollte man z.B. mittels Meta-Regression untersuchen, ob ein bestimmter Faktor, wie zum Beispiel Unterschiede in der untersuchten Population oder der angewendeten Methoden, dafür verantwortlich gemacht werden kann. 


\section{Ziele der Arbeit}

Das Ziel dieser Arbeit war es, mittels einer Metaanalyse auf Grundlage einer breiten wissenschaftlichen Basis zu klären, ob Procalcitonin in der Lage ist, Patienten mit einer Sepsis von solchen $\mathrm{zu}$ unterscheiden, welche an einer systemischen Entzündungsreaktion nicht-bakterieller Genese leiden. Wie sich in wissenschaftlichen Datenbanken nachvollziehen lässt, hat das Interesse an PCT als Sepsismarker gerade in den letzten Jahren stark zugenommen. Seit der zuletzt durchgeführten Metaanalyse 2007 gab es zahlreiche weitere randomisierte, kontrollierte Studien unterschiedlicher Größe und Güte. Unsere Intention war es, alle Primärstudien zum Thema von Gründung der Datenbanken an zu identifizieren und diese anhand einer systematischen Übersichtsarbeit gegenüber zu stellen bzw. deren Qualität $\mathrm{zu}$ prüfen. Um eine Verzerrung zu vermeiden, wurden in die Berechnungen nur Studien eingeschlossen, die unseren vorher festgelegten Einschlusskriterien entsprachen. Unsere Absicht bestand darin einen gepoolten Gesamtschätzer für Sensitivität und Spezifität zu erhalten, der es ermöglicht eine Aussage über den Nutzen im klinischen Alltag zu machen. Ein weiteres Ziel war es, mittels statistischer Analysen festzustellen, ob die Studien heterogen sind und $\mathrm{ob}$ es eine bestimmte Kovariate gibt, die für diese Heterogenität verantwortlich gemacht werden kann. 


\section{Publizierte Originalarbeit}

Procalcitonin as a diagnostic marker for sepsis a systematic review and meta-analysis

Christina Wacker, Anna Prkno, Frank M. Brunkhorst, Peter Schlattmann

The Lancet Infectious Diseases,

May 2013

Volume 13, Issue. 5, p426-435

published online February 1, 2013

doi:10.1016/S1473-3099(12)70323-7 
Articles

\section{(1) Procalcitonin as a diagnostic marker for sepsis: a systematic review and meta-analysis}

Christina Wacker, Anna Prkno, Frank M Brunkhorst*, Peter Schlattmann*

\section{Summary}

Lancet Infect Dis 2013; Background Procalcitonin is a promising marker for identification of bacterial infections. We assessed the accuracy

13: 426-35 and clinical value of procalcitonin for diagnosis of sepsis in critically ill patients.

Published Online

February 1, 2013

Methods We searched Medline, Embase, ISI Web of Knowledge, the Cochrane Library, Scopus, BioMed Central, and Science Direct, from inception to Feb 21, 2012, and reference lists of identified primary studies. We included articles written in English, German, or French that investigated procalcitonin for differentiation of septic patients-those with sepsis, severe sepsis, or septic shock-from those with a systemic inflammatory response syndrome of noninfectious origin. Studies of healthy people, patients without probable infection, and children younger than 28 days were excluded. Two independent investigators extracted patient and study characteristics; discrepancies were resolved by consensus. We calculated individual and pooled sensitivities and specificities. We used $I^{2}$ to test heterogeneity and investigated the source of heterogeneity by metaregression.

Findings Our search returned 3487 reports, of which 30 fulfilled the inclusion criteria, accounting for 3244 patients. Bivariate analysis yielded a mean sensitivity of $0 \cdot 77(95 \%$ CI $0 \cdot 72-0 \cdot 81)$ and specificity of $0 \cdot 79(95 \%$ CI $0 \cdot 74-0 \cdot 84)$ The area under the receiver operating characteristic curve was $0.85(95 \%$ CI $0 \cdot 81-0 \cdot 88)$. The studies had substantial heterogeneity ( $I^{2}=96 \%, 95 \%$ CI $\left.94-99\right)$. None of the subgroups investigated-population, admission category, assay used, severity of disease, and description and masking of the reference standard-could account for the heterogeneity.

Interpretation Procalcitonin is a helpful biomarker for early diagnosis of sepsis in critically ill patients. Nevertheless, he results of the test must be interpreted carefully in the context of medical history, physical examination, and microbiological assessment.

Funding Ministry of Education and Research, the Deutsche Forschungsgemeinschaft, Thuringian Ministry for Education, Science and Culture, the Thuringian Foundation for Technology, Innovation and Research, and the German Sepsis Society.

Introduction

Worldwide, sepsis and its sequelae are still a common cause of acute illness and death in patients with community-acquired and nosocomial infections. ${ }^{1.2}$ The American College of Chest Physicians and the Society of Critical Care Medicine Consensus Conference (Northbrook, IL, USA; August, 1991) defined sepsis as systemic inflammatory response caused by infection. ${ }^{3}$ However, no gold standard exists for proof of infection. Bacteraemia is identified in only about $30 \%$ of patients with sepsis, depending on previous antibiotic treatment. ${ }^{4.5}$ Furthermore, early clinical signs of sepsis, such as fever, tachycardia, and leucocytosis, are non-specific and overlap with signs of systemic inflammatory response syndromes of non-infectious origin, especially in patients who have undergone surgery. Other signs, such as arterial hypotension, thrombocytopenia, or increased lactate concentrations suggest, too late for life-saving treatment, progression to organ dysfunction. Thus, delay in diagnosis and treatment of sepsis increases mortality, prolongs length of hospital stay, and increases costs, ${ }^{6,7}$ highlighting the need for early and reliable diagnostic biomarkers for sepsis.
Several humoral and cellular systems are activated during sepsis, with a subsequent release of various molecules that mediate the host response to infection. Several potential bloodstream biomarkers have been investigated for their ability to diagnose sepsis, estimate its severity, and provide a prognosis. The 116-aminoacid polypeptide procalcitonin had been termed the "the champion so far" for identification of bacterial infections because it has several advantages over other potential biomarkers-ie, wide biological range, short time of induction after bacterial stimulus, and long half-life.

However, only two meta-analyses have investigated the accuracy of procalcitonin for the diagnosis of sepsis, with conflicting results. ${ }^{10.11}$ Both were limited by selected populations, did not include a heterogeneous patient population, and, most importantly, were biased by the choice of a gold standard for the definition of sepsis. Additionally, new studies of procalcitonin have been done since the publication of the meta-analyses and our understanding of procalcitonin is still developing.

We did a meta-analysis to investigate the ability of procalcitonin to differentiate between sepsis and systemic inflammatory response syndromes of 
Articles

non-infectious origin in critically ill patients and address the heterogeneity of patients and the affect of individua covariates.

\section{Methods \\ Search strategy and selection criteria}

We systematically searched Medline (via PubMed), Embase (via OvidSP), ISI Web of Knowledge, the Cochrane Library, Scopus, BioMed Central, and Science Direct for studies that assessed the accuracy of procalcitonin for the diagnosis of sepsis.

Our medical subject heading terms (for Medline), EMTREE terms (for Embase), and text (for others) were "(procalcitonin OR PCT) AND (sepsis OR "bacteria infection" OR "systemic inflammatory response syndrome" OR SIRS)". To reduce the number of results, for searches in Science Direct, Embase, and Scopus, we also used the search terms "NOT (review OR letter OR editorial OR "animal experiment" OR "meeting abstract" OR "proceeding paper" OR "poster presentation" OR "meta-analysis" OR “case report")". We searched the databases between inception and Feb 21, 2012. We also searched the reference list of each primary study identified and of previous systematic reviews.

Studies were included if they assessed the accuracy of procalcitonin for differentiation between critically il patients with sepsis from those who have a systemic inflammatory response syndrome without infection.

To be eligible, studies had to have a well defined reference standard for sepsis, which included the use of definitions established by the American College of Chest Physicians and Society of Critical Care Medicine Consensus Conference ${ }^{3}$ or the German Sepsis Society. ${ }^{12}$ In accordance with these definitions, the presence of infection had to be microbiologically confirmed or at least clinically suspected because of one or more characteristics: white blood cells in a normally sterile body fluid, perforated viscus, radiographic evidence of pneumonia in association with production of purulent sputum, and syndrome associated with a high risk of infection (eg, ascending cholangitis).

Furthermore, the studies had to provide sufficient information to construct the $2 \times 2$ contingency table-ie, false and true positives and negatives were provided.

We only included publications written in English, German, or French. Animal experiments, reviews, correspondences, case reports, expert opinions, and editorials were excluded. We also excluded all studies that involved healthy people, patients without probable infection, and children younger than 28 days.

\section{Procedures}

Two investigators (CW, AP) independently extracted data, including the quality assessment from the retrieved studies. Discrepancies were resolved in a consensus meeting or, if agreement could not be reached, they were resolved by referral to a third investigator (FMB).
The extracted data were general and detailed methodology characteristics, characteristics of the study population (adults or children), setting (emergency department, general ward, or intensive care unit), admission category (surgical or medical), severity of illness (sepsis, severe sepsis, or septic shock), and details of the procalcitonin assays and cutoffs used.

Each investigator also recorded the number of true and false positives and negatives. We contacted the corresponding authors if further information was needed. If no response was received after sending a reminder, the study was excluded.

We assessed the methodological quality of the studies with the Quality Assessment of Diagnostic Accuracy Studies checklist. ${ }^{13}$ We tailored the guidelines for scoring each item of the checklist to our review. ${ }^{14}$ Because overall quality scoring is difficult and should not be included in meta-analyses, ${ }^{15}$ we included only item 9 (description of the reference standard) and item 11 (diagnostic review bias) of the 14 individual quality-related items as covariates in a bivariate random-effects model to test them as possible sources of variation and bias.

\section{Statistical analysis}

We tabulated true positives, false negatives, false positives, and true negatives in patients with sepsis and systemic inflammatory response syndrome, stratified by study. We used the numbers to calculate sensitivity and specificity and a corresponding CI.

To synthesise data, we used an exact binomial rendition $^{16}$ of the bivariate mixed-effects regression

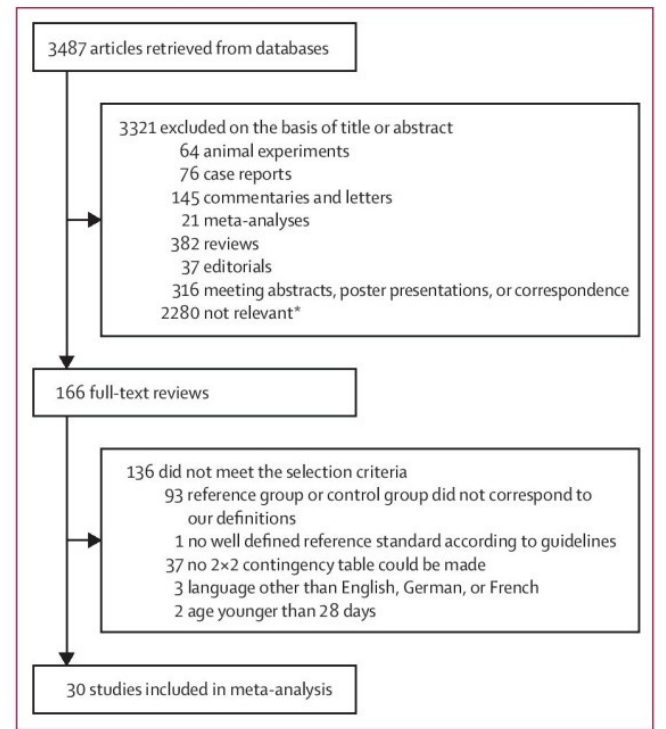

Figure 1: Study selection

Some studies were excluded for more than one reason. *Did not investigate the diagnostic accuracy of procalcitonin as a marker for sepsis. 
model developed by van Houwelingen ${ }^{17,18}$ for metaanalysis of treatment trials, modified for synthesis of diagnostic test data. ${ }^{1920}$ This model does not transform pairs of sensitivity and specificity of individual studies into a single indicator of diagnostic accuracy, but preserves the two-dimensional nature of the data taking into account any correlation between the two.

Based on this model, we estimated mean logit sensitivity and specificity with their standard error and $95 \%$ CIs, the between-study variability in logit sensitivity and specificity, and the covariance between them. We back-transformed these quantities to the original receiver operating curve scale to obtain summary sensitivity, specificity, and diagnostic odds ratios. We then used the derived logit estimates of sensitivity, specificity, and respective variances to construct a hierarchical summary receiver operating curve for procalcitonin with summary operating points for sensitivity and specificity on the curves and a $95 \%$ confidence contour ellipsoid (two-dimensional CI).

We calculated $I^{2}$ to assess heterogeneity. If heterogeneity among studies was recorded, the potential source of heterogeneity was investigated by metaregression. Study-level covariates can be used in metaregression to combine results from multiple studies with attention to between-study variation. We used study-specific covariates such as population or admission category. To investigate publication bias, we constructed effective sample size funnel plots versus the log diagnostic odds ratio and did a regression test of asymmetry. ${ }^{21}$

We calculated $\kappa$ statistics to assess the agreement between the two investigators for assessment of methodological quality.

\begin{tabular}{|c|c|c|c|c|c|c|c|c|c|c|c|c|c|c|c|}
\hline & Year & Population & $\begin{array}{l}\text { Admission } \\
\text { category }\end{array}$ & Setting & $\begin{array}{l}\text { Procalcitonin } \\
\text { assay }\end{array}$ & $\begin{array}{l}\text { Cutoff } \\
\text { (ng/ } \\
\mathrm{mL})\end{array}$ & $n$ & $\begin{array}{l}\text { Prevalence } \\
(\%)\end{array}$ & Severity & TP & FP & $\mathrm{TN}$ & $\mathrm{FN}$ & $\begin{array}{l}\text { Sensitivity } \\
(95 \% \mathrm{Cl})\end{array}$ & $\begin{array}{l}\text { Specificity } \\
(95 \% \mathrm{Cl})\end{array}$ \\
\hline 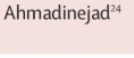 & 2009 & Adult & $\begin{array}{l}\text { Medical and } \\
\text { surgical }\end{array}$ & ED & PCT-Q & 0.5 & 120 & $59 \%$ & No information & 63 & 11 & 38 & 8 & $\begin{array}{l}0.89 \\
(0.79-0.95)\end{array}$ & $\begin{array}{l}0.78 \\
(0.63-0.88)\end{array}$ \\
\hline Al-Nawas ${ }^{25}$ & 1996 & Adult & Medical & . & РCT-LIA & 0.5 & 337 & $36 \%$ & $\begin{array}{l}\text { Sepsis, severe sepsis, } \\
\text { and septic shock }\end{array}$ & 73 & 45 & 170 & 49 & $\begin{array}{l}0.60 \\
(0.51-0.69)\end{array}$ & $\begin{array}{l}0.79 \\
(0.73-0.84)\end{array}$ \\
\hline Arkader $^{26}$ & 2006 & Paediatric & $\begin{array}{l}\text { Medical and } \\
\text { surgical }\end{array}$ & PICU & РCT-LIA & 2 & 28 & $50 \%$ & No information & 12 & 0 & 14 & 2 & $\begin{array}{l}0.86 \\
(0.57-0.98)\end{array}$ & $\begin{array}{l}1.00 \\
(0.77-1.00)\end{array}$ \\
\hline Bell $^{27}$ & 2003 & Adult & $\begin{array}{l}\text { Medical and } \\
\text { surgical }\end{array}$ & ICU & РCT-LIA & 15.75 & 83 & $75 \%$ & No information & 47 & 2 & 19 & 15 & $\begin{array}{l}0.76(0.63- \\
0.86)\end{array}$ & $\begin{array}{l}0.90 \\
(0.70-0.99)\end{array}$ \\
\hline Castelli $^{28}$ & 2004 & Adult & $\begin{array}{l}\text { Medical and } \\
\text { surgical }\end{array}$ & ICU & РCT-LIA & $1 \cdot 2$ & 49 & $69 \%$ & $\begin{array}{l}\text { Sepsis, severe sepsis, } \\
\text { and septic shock }\end{array}$ & 21 & 2 & 13 & 13 & $\begin{array}{l}0.62 \\
(0.44-0.78)\end{array}$ & $\begin{array}{l}0.87 \\
(0.60-0.98)\end{array}$ \\
\hline $\mathrm{Clec}^{\prime} \mathrm{h}^{29}$ & 2006 & Adult & Medical & ICU & PCT-Kryptor & 1 & 76 & $47 \%$ & Septic shock & 29 & 2 & 38 & 7 & $\begin{array}{l}0.81 \\
(0.64-0.92)\end{array}$ & $\begin{array}{l}0.95 \\
(0.83-0.99)\end{array}$ \\
\hline $\mathrm{Clec}^{\prime} \mathrm{h}^{29}$ & 2006 & Adult & Surgical & ICU & PCT-Kryptor & $9 \cdot 7$ & 67 & $46 \%$ & Septic shock & 28 & 9 & 27 & 3 & $\begin{array}{l}0.90 \\
(0.74-0.98)\end{array}$ & $\begin{array}{l}0.75 \\
(0.58-0.88)\end{array}$ \\
\hline Dorizzi $^{30}$ & 2006 & Adult & $\begin{array}{l}\text { Medical and } \\
\text { surgical }\end{array}$ & ICU & РCT-LIA & 1 & 83 & $61 \%$ & $\begin{array}{l}\text { Sepsis, severe sepsis, } \\
\text { and septic shock }\end{array}$ & 42 & 6 & 26 & 9 & $\begin{array}{l}0.82 \\
(0.69-0.92)\end{array}$ & $\begin{array}{l}0.81 \\
(0.64-0.93)\end{array}$ \\
\hline $\mathrm{Du}^{31}$ & 2003 & Adult & $\begin{array}{l}\text { Medical and } \\
\text { surgical }\end{array}$ & ICU & РCT-LAA & 1.6 & 51 & $39 \%$ & $\begin{array}{l}\text { Sepsis, severe sepsis, } \\
\text { and septic shock }\end{array}$ & 16 & 8 & 23 & 4 & $\begin{array}{l}0.80 \\
(0.56-0.94)\end{array}$ & $\begin{array}{l}0.74 \\
(0.55-0.88)\end{array}$ \\
\hline Gainin $^{32}$ & 2006 & Adult & Medical & $\mathrm{HW}$ & PCT-Kryptor & 1 & 93 & $80 \%$ & $\begin{array}{l}\text { Sepsis, severe sepsis, } \\
\text { and septic shock }\end{array}$ & 56 & 9 & 10 & 18 & $\begin{array}{l}0.76 \\
(0.64-0.85)\end{array}$ & $\begin{array}{l}0.53 \\
(0.29-0.76)\end{array}$ \\
\hline Gibot ${ }^{33}$ & 2004 & Adult & Medical & ICU & PCT-LIA & 0.6 & 76 & $62 \%$ & $\begin{array}{l}\text { Sepsis, severe sepsis, } \\
\text { and septic shock }\end{array}$ & 39 & 9 & 20 & 8 & $\begin{array}{l}0.83 \\
(0.69-0.92)\end{array}$ & $\begin{array}{l}0.69 \\
(0.49-0.85)\end{array}$ \\
\hline Groselj-Grenc ${ }^{34}$ & 2009 & Paediatric & $\begin{array}{l}\text { Medical and } \\
\text { surgical }\end{array}$ & PICU & РCT-LIA & 0.28 & 36 & $67 \%$ & $\begin{array}{l}\text { Sepsis, severe sepsis, } \\
\text { and septic shock }\end{array}$ & 20 & 3 & 9 & 4 & $\begin{array}{l}0.83 \\
(0.63-0.95)\end{array}$ & $\begin{array}{l}0.75 \\
(0.43-0.95)\end{array}$ \\
\hline Harbarth ${ }^{35}$ & 2001 & Adult & $\begin{array}{l}\text { Medical and } \\
\text { surgical }\end{array}$ & ICU & РСТ-LIA & 1.1 & 78 & $77 \%$ & $\begin{array}{l}\text { Sepsis, severe sepsis, } \\
\text { and septic shock }\end{array}$ & 58 & 4 & 14 & 2 & $\begin{array}{l}0.97 \\
(0.88-1.00)\end{array}$ & $\begin{array}{l}0.78 \\
(0.52-0.94)\end{array}$ \\
\hline $\mathrm{Hsu}^{36}$ & 2011 & Adult & Medical & ICU & PCT-Kryptor & $2 \cdot 2$ & 66 & $83 \%$ & $\begin{array}{l}\text { Severe sepsis and } \\
\text { septic shock }\end{array}$ & 31 & 0 & 11 & 24 & $\begin{array}{l}0.56 \\
(0.42-0.70)\end{array}$ & $\begin{array}{l}1.00 \\
(0.72-1.00)\end{array}$ \\
\hline Ivancevic ${ }^{3 y}$ & 2008 & Adult & Surgical &. & РCT-LIA & 1.1 & 63 & $65 \%$ & No information & 34 & 5 & 17 & 7 & $\begin{array}{l}0.83 \\
(0.68-0.93)\end{array}$ & $\begin{array}{l}0.77 \\
(0.55-0.92)\end{array}$ \\
\hline Jimeno $^{38}$ & 2004 & Adult & Medical & .. & PCT-LIA & 0.5 & 104 & $39 \%$ & No information & 17 & 5 & 58 & 24 & $\begin{array}{l}0.41 \\
(0.26-0.58)\end{array}$ & $\begin{array}{l}0.92 \\
(0.82-0.97)\end{array}$ \\
\hline Kofoed $^{39}$ & 2007 & Adult & Medical & $\begin{array}{l}\mathrm{HW} \text { and } \\
\mathrm{ED}\end{array}$ & PCT-Kryptor & 0.25 & 151 & $64 \%$ & No information & 77 & 23 & 32 & 19 & $\begin{array}{l}0.80 \\
(0.71-0.88)\end{array}$ & $\begin{array}{l}0.58 \\
(0.44-0.71)\end{array}$ \\
\hline Latour-Perez ${ }^{40}$ & 2010 & Adult & $\begin{array}{l}\text { Medical and } \\
\text { surgical }\end{array}$ & ICU & $\mathrm{PCT}-\mathrm{Q}$ & 0.5 & 114 & $63 \%$ & $\begin{array}{l}\text { Sepsis, severe sepsis, } \\
\text { and septic shock }\end{array}$ & 53 & 5 & 37 & 19 & $\begin{array}{l}0.74 \\
(0.62-0.83)\end{array}$ & $\begin{array}{l}0.88 \\
(0.74-0.96)\end{array}$ \\
\hline \multirow[t]{2}{*}{ Meynaar" } & 2011 & Adult & $\begin{array}{l}\text { Medical and } \\
\text { surgical }\end{array}$ & ICU & PCT-Kryptor & 2 & 76 & $42 \%$ & $\begin{array}{l}\text { Sepsis, severe sepsis, } \\
\text { and septic shock }\end{array}$ & 31 & 9 & 35 & 1 & $\begin{array}{l}0.97 \\
(0.84-1.00)\end{array}$ & $\begin{array}{l}0.80 \\
(0.65-0.90)\end{array}$ \\
\hline & & & & & & & & & & & & & & \multicolumn{2}{|c|}{ (Continues on next page) } \\
\hline
\end{tabular}


Articles

\begin{tabular}{|c|c|c|c|c|c|c|c|c|c|c|c|c|c|c|c|}
\hline & Year & Population & $\begin{array}{l}\text { Admission } \\
\text { category }\end{array}$ & Setting & $\begin{array}{l}\text { Procalcitonin } \\
\text { assay }\end{array}$ & $\begin{array}{l}\text { Cutoff } \\
\text { (ng/ } \\
\mathrm{mL})\end{array}$ & n & $\begin{array}{l}\text { Prevalence } \\
\text { (\%) }\end{array}$ & Severity & TP & FP & TN & $\mathrm{FN}$ & $\begin{array}{l}\text { Sensitivity } \\
(95 \% \mathrm{Cl})\end{array}$ & $\begin{array}{l}\text { Specificity } \\
(95 \% \mathrm{Cl})\end{array}$ \\
\hline \multicolumn{16}{|c|}{ (Continued from previous page) } \\
\hline Naeini $^{2}$ & 2006 & Adult & $\begin{array}{l}\text { Medical and } \\
\text { surgical }\end{array}$ & .. & PCT-Q & 0.5 & 50 & $50 \%$ & $\begin{array}{l}\text { Sepsis, severe sepsis, } \\
\text { and septic shock }\end{array}$ & 22 & 1 & 24 & 3 & $\begin{array}{l}0.88 \\
(0.69-0.97)\end{array}$ & $\begin{array}{l}0.96 \\
(0.80-1.00)\end{array}$ \\
\hline Oshita ${ }^{43}$ & 2010 & Adult &. & .* & PCT-Q & 0.5 & 168 & $67 \%$ & No information & 76 & 11 & 45 & 36 & $\begin{array}{l}0.68 \\
(0.58-0.76)\end{array}$ & $\begin{array}{l}0.80 \\
(0.68-0.90)\end{array}$ \\
\hline Pavcnik-Arnol ${ }^{14}$ & 2007 & Paediatric & $\begin{array}{l}\text { Medical and } \\
\text { surgical }\end{array}$ & PICU & PCT-Kryptor & 5.79 & 49 & $61 \%$ & $\begin{array}{l}\text { Sepsis, severe sepsis, } \\
\text { and septic shock }\end{array}$ & 17 & 2 & 17 & 13 & $\begin{array}{l}0.57 \\
(0.37-0.75)\end{array}$ & $\begin{array}{l}0.89 \\
(0.67-0.99)\end{array}$ \\
\hline Ruiz-Alvarez $z^{45}$ & 2009 & Adult & $\begin{array}{l}\text { Medical and } \\
\text { surgical }\end{array}$ & ICU & PCT-Kryptor & 0.32 & 103 & $76 \%$ & $\begin{array}{l}\text { Sepsis, severe sepsis, } \\
\text { and septic shock }\end{array}$ & 65 & 9 & 16 & 13 & $\begin{array}{l}0.83 \\
(0.73-0.91)\end{array}$ & $\begin{array}{l}0.64 \\
(0.43-0.82)\end{array}$ \\
\hline Sakr ${ }^{46}$ & 2008 & Adult & Surgical & ICU & PCT-LIA & 2 & 327 & $36 \%$ & $\begin{array}{l}\text { Sepsis, severe sepsis, } \\
\text { and septic shock }\end{array}$ & 82 & 92 & 116 & 37 & $\begin{array}{l}0.69 \\
(0.60-0.77)\end{array}$ & $\begin{array}{l}0.56 \\
(0.49-0.63)\end{array}$ \\
\hline Selberg ${ }^{47}$ & 2000 & Adult & Medical & ICU & PCT-LIA & $3 \cdot 3$ & 33 & $67 \%$ & $\begin{array}{l}\text { Sepsis and severe } \\
\text { sepsis }\end{array}$ & 19 & 5 & 6 & 3 & $\begin{array}{l}0.86 \\
(0.65-0.97)\end{array}$ & $\begin{array}{l}0.55 \\
(0.23-0.83)\end{array}$ \\
\hline $\operatorname{Simon}^{48}$ & 2008 & Paediatric & $\begin{array}{l}\text { Medical and } \\
\text { surgical }\end{array}$ & PICU & PCT-LIA & 2.5 & 64 & $39 \%$ & No information & 17 & 10 & 29 & 8 & $\begin{array}{l}0.68 \\
(0.46-0.85)\end{array}$ & $\begin{array}{l}0.74 \\
(0.58-0.87)\end{array}$ \\
\hline Suprin ${ }^{49}$ & 2000 & Adult & Medical & ICU & PCT-LIA & 2 & 95 & $79 \%$ & $\begin{array}{l}\text { Sepsis, severe sepsis, } \\
\text { and septic shock }\end{array}$ & 49 & 6 & 14 & 26 & $\begin{array}{l}0.65 \\
(0.53-0.76)\end{array}$ & $\begin{array}{l}0.70 \\
(0.46-0.88)\end{array}$ \\
\hline Tsalikik & 2011 & Adult & .. & ED & PCT-Kryptor & 0.1 & 336 & $74 \%$ & $\begin{array}{l}\text { Sepsis, severe sepsis, } \\
\text { and septic shock }\end{array}$ & 168 & 33 & 56 & 79 & $\begin{array}{l}0.68 \\
(0.62-0.74)\end{array}$ & $\begin{array}{l}0.63 \\
(0.52-0.73)\end{array}$ \\
\hline Tsangaris $^{51}$ & 2009 & Adult & $\begin{array}{l}\text { Medical and } \\
\text { surgical }\end{array}$ & ICU & PCT-Kryptor & 1 & 50 & $54 \%$ & $\begin{array}{l}\text { Sepsis, severe sepsis, } \\
\text { and septic shock }\end{array}$ & 19 & 2 & 21 & 8 & $\begin{array}{l}0.70 \\
(0.50-0.86)\end{array}$ & $\begin{array}{l}0.91 \\
(0.72-0.99)\end{array}$ \\
\hline Tugru| $\left.\right|^{22}$ & 2002 & Adult & $\begin{array}{l}\text { Medical and } \\
\text { surgical }\end{array}$ & ICU & PCT-LIA & $1 \cdot 31$ & 85 & $88 \%$ & $\begin{array}{l}\text { Sepsis, severe sepsis, } \\
\text { and septic shock }\end{array}$ & 55 & 2 & 8 & 20 & $\begin{array}{l}0.73 \\
(0.62-0.83)\end{array}$ & $\begin{array}{l}0.80 \\
(0.44-0.97)\end{array}$ \\
\hline Wanner ${ }^{53}$ & 2000 & Adult & Surgical & $\begin{array}{l}\mathrm{ED} \text { and } \\
\mathrm{ICU}\end{array}$ & PCT-LIA & 1.5 & 133 & $34 \%$ & No information & 34 & 20 & 68 & 11 & $\begin{array}{l}0.76 \\
(0.60-0.87)\end{array}$ & $\begin{array}{l}0.77 \\
(0.67-0.86)\end{array}$ \\
\hline
\end{tabular}

We used the MIDAS module ${ }^{22}$ for STATA (version 12) for the bivariate summary receiver operating curve analysis and to calculate $\mathrm{K}$ statistics. We used Proc GLIMMIX in SAS (version 9.3) to do the metaregression. Graphs were produced with the MIDAS module and the Quality Assessment of Diagnostic Accuracy Studies module for STATA.

\section{Role of the funding source}

The sponsor of the study had no role in study design, data collection, data analysis, data interpretation, or writing of the report. The corresponding author had full access to all the data in the study and had final responsibility for the decision to submit for publication.

\section{Results}

Our database search retrieved 3487 articles. After reviewing the titles and abstracts, we excluded 3321. After a full text review we excluded a further 136, leaving 30 studies for inclusion (figure 1). Because in one study investigators reported diagnostic accuracy separately for medical and surgical patients, the study was divided into two parts, thus we analysed 31 datasets. Search of the reference lists of the identified articles and previous systematic reviews ${ }^{10.1 .23}$ did not identify any more relevant articles.
The table shows the main study characteristics. 3244 critically ill patients were included in the analysis, of whom 1863 (57\%) had sepsis and 1381 (43\%) had systemic inflammatory response syndrome of noninfectious origin. 21 of 30 studies reported classification of severity of illness (sepsis, severe sepsis, or septic shock). Of 1173 patients, 499 (42\%) had sepsis, $234(20 \%)$ had severe sepsis, and $440(38 \%)$ had septic shock.

The prevalence of sepsis among studies ranged between $34 \%$ and $88 \%$ (mean $60 \%$ ). Only four studies were done in a paediatric setting, whereas 27 investigated adult patients (table). Sites of infectioneg, lung, abdomen, bloodstream, urinary tract-varied. The source of infection (community-acquired or nosocomial) also differed between studies.

Most studies were done in intensive care units, four of them in a paediatric intensive care unit, and most (20 of 30) were done in Europe (table). The cutoff for procalcitonin concentration differed substantially between studies (median $1 \cdot 1 \mathrm{ng} / \mathrm{mL}$, IQR $0 \cdot 5-2 \cdot 0$ ).

Most studies (17 of 30) used a quantitative manual procalcitonin assay for diagnosis of sepsis (table). The appendix shows assay characteristics, the metho- see Online for appendix dological quality of the included studies according to the Quality Assessment of Diagnostic Accuracy Studies 


\section{Articles}

checklist, ${ }^{13}$ how the studies scored on each item, and how the items were assessed. We omitted item 12 of the checklist (clinical data) because the index test is fully automated and no further clinical data are needed to interpret the test results.

The inter-rater reliability for assessment of quality items was $0.59(\mathrm{p}<0 \cdot 0001)$. Overall, the methodological quality was moderate. None of the studies fulfilled all of the items, but all studies fulfilled at least four items. 22 studies

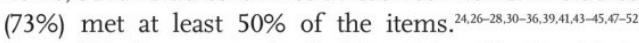
Items 3 (reference standard), 5 (partial verification bias), 6 (differential verification bias), and 14 (withdrawals) were fulfilled by all studies. Reports of test review bias (item 10) and uninterpretable results (item 13) were poor (appendix). We identified publication bias by Deeks' regression test of asymmetry $(t=4 \cdot 12 ; \mathrm{p}<0 \cdot 0005$; appendix).

Pooled sensitivity was $0.77(95 \%$ CI $0.72-0.81)$ and pooled specificity was 0.79 (95\% CI 0.74-0.84; figure 2$)$.
The area under the receiver operating characteristic curve was $0 \cdot 85$ (95\% CI 0.81-0.88; figure 3). Substantial heterogeneity exists among the studies (overall $I^{2}$ for bivariate model 96\%, 95\% CI 94-99). We recorded no evidence of a threshold effect (tested with the STATA MIDAS module). The proportion of heterogeneity probably caused by different cutoffs was small $(0 \cdot 05)$. To identify the source of heterogeneity, we did metaregression analyses.

To compare medical with surgical patients we did a stratified bivariate regression analysis. We obtained data from 13 studies (nine provided data for medical patients and four provided data for surgical patients). The diagnostic accuracy in surgical patients was higher than that in medical patients as measured by the area under the summary receiver operating characteristic curve $(0 \cdot 83$ [95\% CI $0 \cdot 80-0 \cdot 86]$ vs $0 \cdot 79[0 \cdot 75-0 \cdot 83]$; not tested for significance). We also compared adult with paediatric

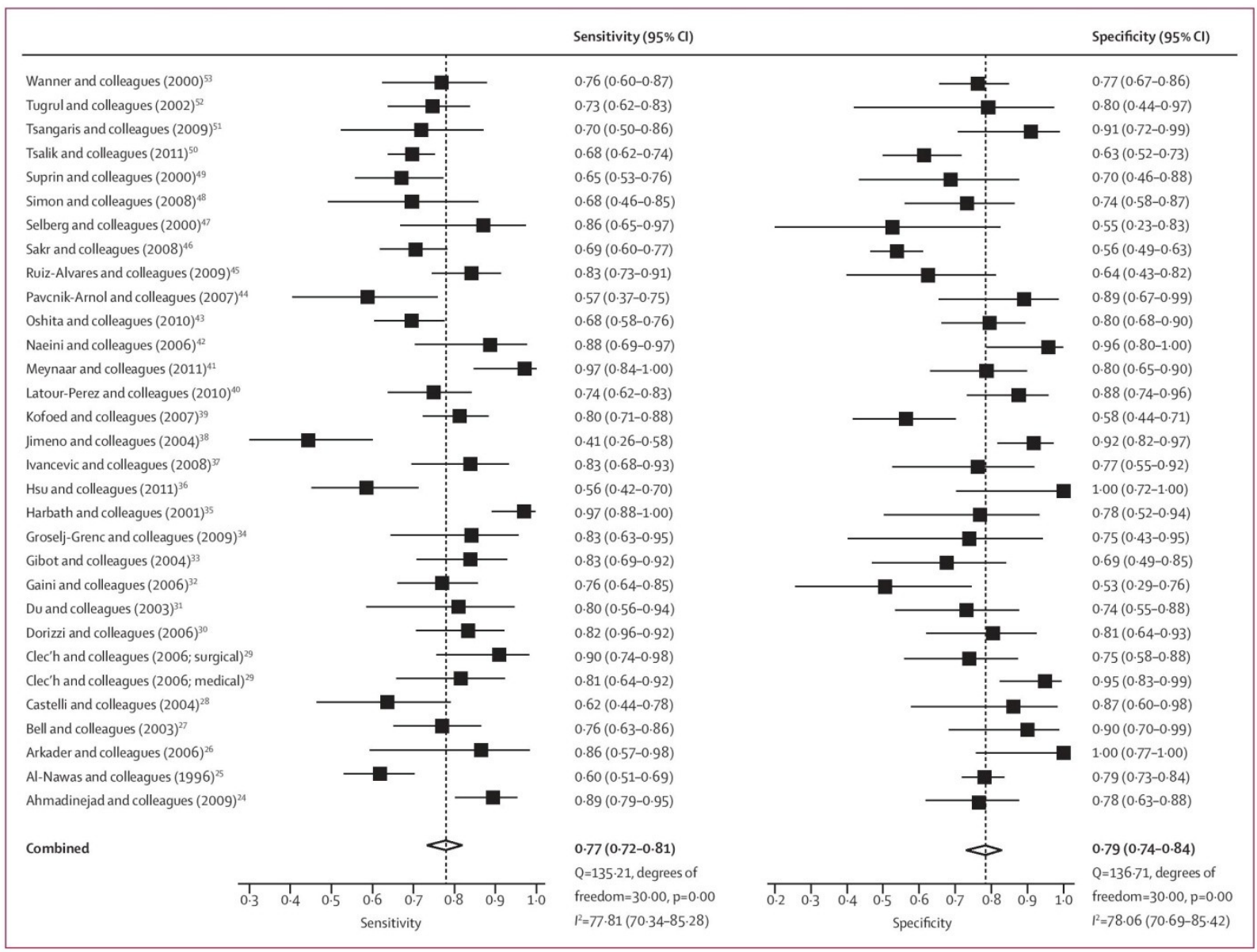

Figure 2: Sensitivity and specificity of procalcitonin assay for diagnosis of sepsis 
Articles

patients $(0 \cdot 85[0 \cdot 82-0 \cdot 88]$ vs $0 \cdot 85[0 \cdot 81-0 \cdot 88]$; not tested for significance). Analysis of the other covariates yielded no significant results (data not shown). Thus, the heterogeneity could not be explained by metaregression analysis.

\section{Discussion}

Procalcitonin can differentiate effectively between sepsis and systemic inflammatory response syndrome of noninfectious origin. Previously, two meta-analyses have investigated the diagnostic accuracy of procalcitonin in critically ill patients, with conflicting results. ${ }^{10.11}$

In a meta-analysis from 2006, including studies published between April, 1996, and October, 2004, Uzzan and colleagues ${ }^{11}$ reported that the summary receiver operating characteristics curve for procalcitonin was better than for C-reactive protein for identification of sepsis. However, the investigators restricted the population to surgery or trauma patients. Therefore, no conclusion can be drawn for patients other than surgical. Furthermore, the researchers did not assess the heterogeneity of patients from different settings, with different sites of infection, or other study-specific covariates.

In a meta-analysis from 2007, including 18 studies published between April, 1996, and November, 2005, Tang and colleagues ${ }^{10}$ concluded that procalcitonin is not able to discriminate between sepsis and systemic inflammatory response syndrome. The diagnostic accuracy of procalcitonin was low; mean sensitivity and specificity were both $71 \%(95 \%$ 67-76) and the area under the summary receiver operator characteristic curve was 0.78 (95\% CI $0.73-83)$. However, their findings were heavily biased because of their selection criteria. First, studies were excluded that had sites of infection typical in sepsis, such as abdominal sepsis, pancreatitis, or meningitis. Second, studies that assessed the ability of procalcitonin to diagnose septic shock were excluded. Because progression of sepsis to septic shock is associated with an increase in procalcitonin concentration, ${ }^{1}$ exclusion of patients with septic shock could reduce the overall estimate of diagnostic accuracy. To prevent systematic bias, we included all eligible studies that investigated the diagnostic capacity of procalcitonin in the continuum from sepsis to severe sepsis and to septic shock. Third, they included studies that assessed patients who did not have systemic inflammatory response syndrome or who were not critically ill, which might cause underestimation of diagnostic accuracy.

Accordingly, 23 studies included in the previous metaanalyse $^{10,11}$ were excluded from our systematic review because 13 included healthy controls or patients who did not have systemic inflammatory response syndrome in the control group, ${ }^{5+66}$ and seven did not provide clear definitions for the target condition or included patients who had infection without systemic inflammatory response syndrome and thus were not in accordance

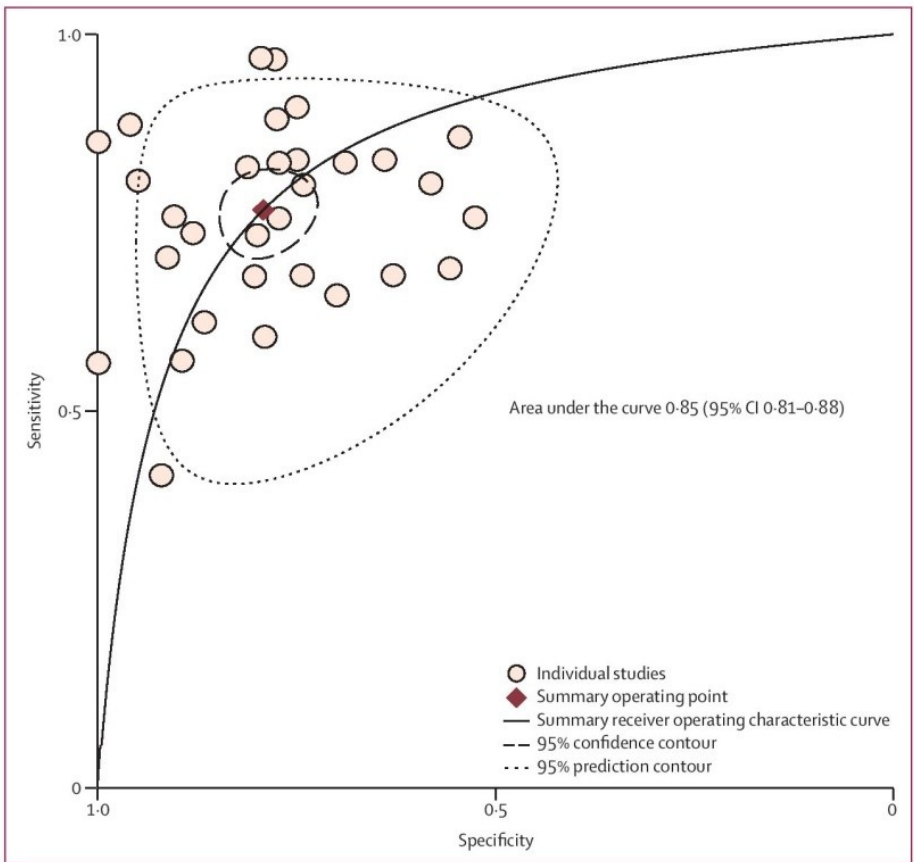

Figure 3: Summary receiver operating characteristic curve

Also shows $95 \%$ confidence contour and $95 \%$ prediction contour.

with our selection criteria. ${ }^{54,6+69}$ Furthermore, four studies had insufficient information to construct the $2 \times 2$ contingency table..$^{70-73}$ One investigated the predictive value of procalcitonin for tumour necrosis factor $\alpha$ and interleukin 6 concentrations. ${ }^{74}$ Another did multiple measurements in several patients ${ }^{75}$ and one study investigated the prognostic value of procalcitonin for infection after cardiac surgery. ${ }^{76}$

Furthermore, the meta-analysis of Tang and colleagues ${ }^{10}$ has substantial shortcomings in its quantitative data analysis. It summarised pairs of sensitivity and specificity into a single measure of diagnostic accuracy. Thus, important information is missing. To retain the two-dimensional character, we used the bivariate mixedeffects regression model.

Our meta-analysis has several limitations. ${ }^{\pi}$ First, we detected substantial heterogeneity between studies but none of the study characteristics were responsible for the majority of this heterogeneity. The studies differ in several ways-eg, methodological quality, patients' clinical spectrum, admission category, and procalcitonin assay used. Thus, further unrecorded differences between the studies probably contribute to the heterogeneity. Use of a more homogenous population would solve this difficulty, but would cause selection bias.

Second, a reliable test of infection is still absent, so observational studies are biased by the choice of 
Articles

gold standard. According to our inclusion criteria, the presence of infection had to be microbiologically confirmed or at least clinically suspected. All included studies fulfilled this requirement (appendix), but most did not provide much detailed information about how infection was proved. Nevertheless, depending on previous antibiotic treatment, bacteraemia occurs in only about $30 \%$ of patients with sepsis..$^{45}$ Additionally, absence of standardisation of clinical and radiological findings could cause interobserver variability, which could lead to false-negative or false-positive judgments about the patient's medical condition. We only included studies that had a well defined reference standard for sepsis. Nevertheless, we do not know definitively whether all patients with infection were identified as such.

Third, implementation of some studies was reported poorly, especially with regard to uninterpretable results and test review bias (appendix). To minimise resultant bias and to ensure more homogeneity, investigators should use the Standards for Reporting of Diagnostic Accuracy checklist ${ }^{78}$ and also consider using the Quality Assessment of Diagnostic Accuracy Studies checklist. ${ }^{13}$

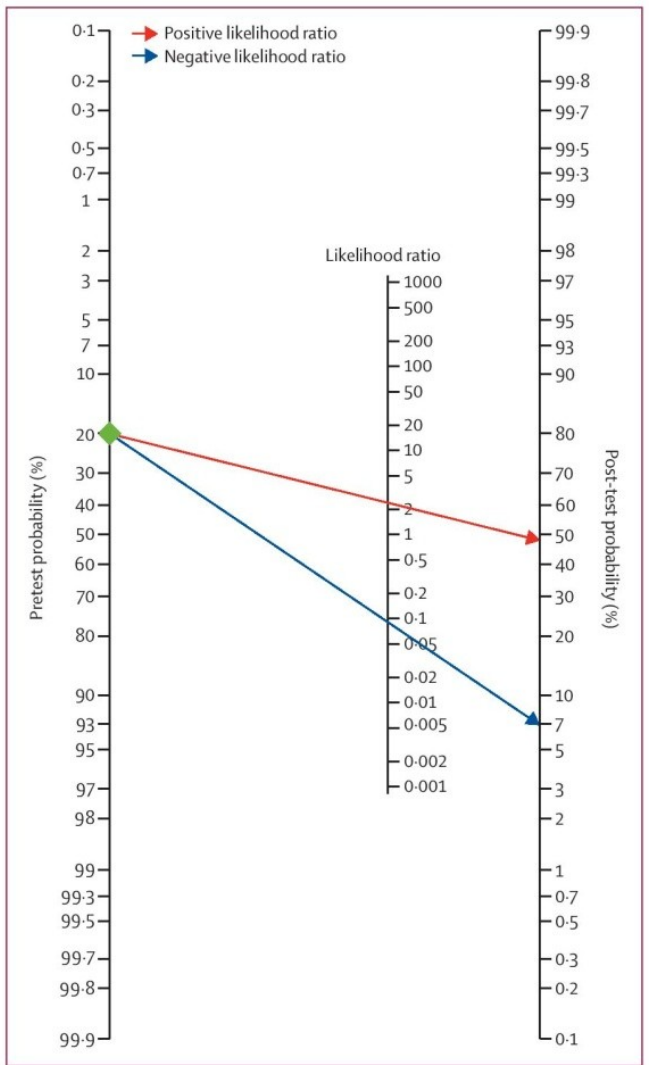

Figure 4: Fagan nomogram of the procalcitonin test for diagnosis of sepsis
Fourth, we detected publication bias. Studies with desirable results are more likely to be published, which can lead to an overestimation of overall diagnostic accuracy. To solve this problem, we looked again for further studies by searching the databases and reference lists of primary studies, but could not identify additional relevant articles. Finally, we only included studies written in German, English, or French, which might have affected our findings.

The cutoffs that separated patients who had sepsis from those who did not varied greatly between studies. Some had a cutoff that led to the most favourable results for diagnostic accuracy. Others gave sensitivity and specificity at different thresholds. The difficulty is that the cutoffs were not subsequently validated. The values of diagnostic accuracy are correlated negatively with each other. To change the cutoff means changing sensitivity at the cost of specificity or vice versa. False-negative results leading to denial of treatment could be fatal in sepsis. However, to prevent the development of antibiotic resistance, and increased side-effects and costs, critically ill patients without bacterial infection should be identified correctly. Thus, a rational threshold is needed. We recommend different phases in testing diagnostic accuracy. First, investigators should examine the validity of procalcitonin in a selected group of patients to find a rational cutoff. Second, to ascertain diagnostic value in everyday clinical practice, the established cutoff has to be validated in a diagnostic controlled trial.

The most important feature of a biomarker is its potential to change clinical decision making. In recent years, cutoffs between 0.1 and $0.5 \mathrm{ng} / \mathrm{mL}$ have been calculated in patients with lower respiratory tract infections. ${ }^{79}$ Our meta-analysis provides important information for critically ill patients, for whom diagnostic decision making is of upmost importance. The median cutoff of the studies included was $1.1 \mathrm{ng} / \mathrm{mL}$ (IQR $0 \cdot 5-2 \cdot 0$ ). The absence of a clinical threshold effect suggests that a cutoff of between 1.0 and $2.0 \mathrm{ng} / \mathrm{mL}$ is helpful for discrimination of patients with sepsis from other inflammatory conditions, in accordance with recommendations. ${ }^{80}$

Likelihood ratios and post-test probabilities are also relevant for clinicians. They provide information about the likelihood that a patient with a positive or negative test actually has sepsis or not. In our study, both likelihood ratio and post-test probability were moderate (figure 4). A positive likelihood ratio of 4 implies that a person with disease is four-times more likely to have a positive test result than is a healthy person. Given a pretest probability of $20 \%$, the post-test probability for a positive test result is $48 \%$ (figure 4 ). Likewise a negative likelihood ratio of 0.29 reduces the post-test probability to $7 \%$ for a negative test result. However, these likelihood ratios are calculated from dichotomised data. The result of the procalcitonin test is either positive or negative. The disadvantage of making data dichotomous is that 
useful information is lost. ${ }^{81}$ Because procalcitonin concentrations rise as disease severity advances ${ }^{56}$ patients with a high procalcitonin concentration are more likely to have sepsis than are patients with a low procalcitonin concentration. To provide more precise information about the reliability of the test, we suggest calculating likelihood ratios based on multiple cutoffs.

As our results show, procalcitonin is not a perfect marker for diagnosis of sepsis, but an ideal marker does not exist. Sepsis is a pathophysiological process rather than a specific syndrome and is too complex to be described by a single measure. Nevertheless, procalcitonin is one of the most promising parameters. Several other mediators and molecules of the host response to infection-C-reactive protein, soluble TREM1, interleukin 6, interleukin 8, and soluble PLAUR-have been investigated, but with no outstanding result. ${ }^{23,35.0082}$

In conclusion, procalcitonin is a helpful marker for diagnosis of sepsis in critically ill patients. However, it cannot be recommended as the single definitive test for sepsis diagnosis, but rather it must be interpreted in context with information from careful medical history, physical examination, and when feasible, microbiological assessment. Moreover, continuing re-evaluation during the course of disease is advisable.

\section{Contributors}

CW had the idea for and designed the study, searched the scientific literature, collected, analysed, and interpreted data, and wrote and critically revised the report. AP searched the scientific literature, collected data, and drafted and critically revised the report. FMB had the idea for and designed the study, interpreted data, drafted and critically revised the report, supervised the study, and gave administrative, technical, and material support. PS had the idea for and designed the study, statistically analysed and interpreted the data, drafted and critically revised the report, supervised the study, and gave administrative, technical, and material support.

\section{Conflicts of interest}

We declare that we have no conflicts of interest.

\section{Acknowledgments}

The work was supported by the German Centre for Sepsis Control \& Care, funded by the Ministry of Education and Research (grant number $01 \mathrm{E0}$ 1002), the Deutsche Forschungsgemeinschaft (Schl 3-1), Thuringian Ministry for Education, Science and Culture (ProExcellence; PE 108-2), the Thuringian Foundation for Technology, Innovation and Research, and the German Sepsis Society.

\section{References}

1 Angus DC, Linde-Zwirble WT, Lidicker J, Clermont G, Carcillo J, Pinsky MR. Epidemiology of severe sepsis in the United States: analysis of incidence, outcome,

2 Martin GS, Mannino DM, Eaton S, Moss M. The epidemiology of sepsis in the United States from 1979 through 2000. N Engl J Med 2003; 348: 1546-54

3 Bone RC, Balk RA, Cerra FB, et al. Definitions for sepsis and organ failure and guidelines for the use of innovative therapies in sepsis. The ACCP/SCCM Consensus Conference Committee. American College of Chest Physicians/Society of Critical Care Medicine. 1992 Chest 2009; 136 (suppl): e28.

4 Bates DW, Cook EF, Goldman L, Lee TH. Predicting bacteremia in hospitalized patients. A prospectively validated model. hospitalized patients. A prospective

5 Bates DW, Sands K, Miller E, et al. Predicting bacteremia in patient with sepsis syndrome. Academic Medical Center Consortium Sepsis Project Working Group. J Infect Dis 1997; 176: 1538-51.
6 Garnacho-Montero J, Ortiz-Leyba C, Herrera-Melero I, et al, Mortality and morbidity attributable to inadequate empirical antimicrobial therapy in patients admitted to the ICU with sepsis: a matched cohort study. J Antimicrob Chemother 2008; 61: 436-41

7 Pittet D, Rangel-Frausto S, Li N, et al. Systemic inflammatory response syndrome, sepsis, severe sepsis and septic shock: incidence, morbidities and outcomes in surgical ICU patients. Intensive Care Med 1995; 21: 302-09.

8 Moyer MW. New biomarkers sought for improving sepsis management and care. Nat Med 2012; 18: 999.

9 Dandona P, Nix D, Wilson MF, et al. Procalcitonin increase after endotoxin injection in normal subjects. J Clin Endocrinol Metab 1994; 79: 1605-08

10 Tang BM, Eslick GD, Craig JC, McLean AS. Accuracy of procalcitonin for sepsis diagnosis in critically ill patients: systematic review and meta-analysis. Lancet Infect Dis 2007; 7: 210-17.

11 Uzzan B, Cohen R, Nicolas P, Cucherat M, Perret GY. Procalcitonin as a diagnostic test for sepsis in critically ill adults and after surgery or trauma: a systematic review and meta-analysis. Crit Care Med -2003.

12 Reinhart K, Brunkhorst FM, Bone HG, et al. Prevention, diagnosis, treatment, and follow-up care of sepsis. First revision of the S2k Guidelines of the German Sepsis Society (DSG) and the German Interdisciplinary Association for Intensive and Emergency Care Medicine (DIVI). Anaesthesist 2010; 59: 347-70 (in German).

13 Whiting P, Rutjes AW, Reitsma JB, Bossuyt PM, Kleijnen J. The development of QUADAS: a tool for the quality assessment of studies of diagnostic accuracy included in systematic reviews. BMC Med Res Methodol 2003; 3:25.

14 Whiting PF, Weswood ME, Rutjes AW, Reitsma JB, Bossuyt PN, Kleijnen J. Evaluation of QUADAS, a tool for the quality assessmen of diagnostic accuracy studies. BMC Med Res Methodol 2006; 6: 9

15 Whiting P, Harbord R, Kleijnen J. No role for quality scores in systematic reviews of diagnostic accuracy studies. BMC Med Res Methodol 2005; 5: 19.

$16 \mathrm{Chu} \mathrm{H}$, Cole SR. Bivariate meta-analysis of sensitivity and specificity with sparse data: a generalized linear mixed model approach. J Clin Epidemiol 2006; 59: 1331-32.

17 Van Houwelingen $\mathrm{HC}$, Zwinderman $\mathrm{KH}$, Stijnen T. A bivariate approach to meta-analysis. Stat Med 1993; 12: 2273-84.

18 van Houwelingen HC, Arends LR, Stijnen T. Advanced methods in meta-analysis: multivariate approach and meta-regression. Stat Med 2002; 21: 589-624.

19 Reitsma JB, Glas AS, Rutjes AW, Scholten RJ, Bossuyt PM, Zwinderman $\mathrm{AH}$. Bivariate analysis of sensitivity and specificity produces informative summary measures in diagnostic reviews. J Clin Epidemiol 2005; 58: 982-90.

20 Riley RD, Abrams KR, Sutton AJ, Lambert PC, Thompson JR. Bivariate random-effects meta-analysis and the estimation of Bivariate random-effects meta-analysis and the estimation of

21 Deeks JJ, Macaskill P, Irwig L. The performance of tests of publication bias and other sample size effects in systematic reviews of diagnostic test accuracy was assessed. J Clin Epidemiol 2005 58: 882-93.

22 Dwamena BA. Midas: a program for meta-analytical integration of diagnostic accuracy studies in stata. 2007. University of Michigan. http://sitemaker.umich.edu/metadiagnosis/midas_home (accessed Jan 15, 2013).

23 Simon L, Gauvin F, Amre DK, Saint-Louis P, Lacroix J. Serum procalcitonin and C-reactive protein levels as markers of bacteria infection: a systematic review and meta-analysis. Clin Infect Dis 2004; 39: 206-17.

24 Ahmadinejad Z, Dadsetan B, Jalili M, Soudbakhsh A, Rasolinejad M. Evaluation of serum procalcitonin in patients with systemic inflammatory response syndrome with and without infection. Acta Med Iran 2009; 47: 383-88.

25 Al-Nawas B, Krammer I, Shah PM. Procalcitonin in diagnosis of severe infections. Eur J Med Res 1996; 1: 331-33.

26 Arkader R, Troster EJ, Lopes MR, et al. Procalcitonin does discriminate between sepsis and systemic inflammatory response syndrome. Arch Dis Child 2006: 91: 117-20.

27 Bell K, Wattie M, Byth K, et al. Procalcitonin: a marker of bacteraemia in SIRS. Anaesth Intensive Care 2003; 31: 629-36. 
Articles

28 Castelli GP, Pognani C, Meisner M, Stuani A, Bellomi D, Sgarbi L. Procalcitonin and C-reactive protein during systemic inflammatory response syndrome, sepsis and organ dysfunction. Crit Care 2004, 8: R234-42.

29 Clec'h C, Fosse JP, Karoubi P, et al. Differential diagnostic value of procalcitonin in surgical and medical patients with septic shock. Crit Care Med 2006; 34: 102-07

30 Dorizzi RM, Polati E, Sette P, Ferrari A, Rizzotti P, Luzzani A Procalcitonin in the diagnosis of inflammation in intensive care units. Clin Biochem 2006; 39: 1138-43.

31 Du B, Pan J, Chen D, Li Y. Serum procalcitonin and interleukin-6 levels may help to differentiate systemic inflammatory response of infectious and non-infectious origin. Chin Med J (Engl) 2003; 116: 538-42.

32 Gaini S, Koldkjaer OG, Pedersen C, Pedersen SS. Procalcitonin, lipopolysaccharide-binding protein, interleukin-6 and C-reactive protein in community-acquired infections and sepsis: a prospective study, Crit Care 2006; 10: R53.

33 Gibot S, Kolopp-Sarda MN, Bene MC, et al. Plasma level of a triggering receptor expressed on myeloid cells-1: its diagnostic accuracy in patients with suspected sepsis. Ann Intern Med 2004 141: 9-15.

34 Groselj-Grenc M, Ihan A, Pavcnik-Arnol M, Kopitar AN Gmeiner-Stopar T, Derganc M. Neutrophil and monocyte CD64 indexes, lipopolysaccharide-binding protein, procalcitonin and C-reactive protein in sepsis of critically ill neonates and children. Intensive Care Med 2009; 35: 1950-58.

35 Harbarth S, Holeckova K, Froidevaux C, et al. Diagnostic value of procalcitonin, interleukin-6, and interleukin-8 in critically ill patients admitted with suspected sepsis. Am J Respir Crit Care Med 2001; 164: 396-402.

36 Hsu KH, Chan MC, Wang JM, Lin LY, Wu CL. Comparison of Fcgamma receptor expression on neutrophils with procalcitonin for the diagnosis of sepsis in critically ill patients. Respirology 2011; 16: $152-60$.

37 Ivancevic N, Radenkovic D, Bumbasirevic V, et al. Procalcitonin in preoperative diagnosis of abdominal sepsis. Langenbecks Arch Surg 2008; 393: 397-403

38 Jimeno A, Garcia-Velasco A, del Val O, et al. Assessment of procalcitonin as a diagnostic and prognostic marker in patients with solid tumors and febrile neutropenia. Cancer 2004; 100: 2462-69.

39 Kofoed K, Andersen O, Kronborg G, et al. Use of plasma C-reactive protein, procalcitonin, neutrophils, macrophage migration inhibitory factor, soluble urokinase-type plasminogen activat receptor, and soluble triggering receptor expressed on myeloid cells-1 in combination to diagnose infections: a prospective study. Crit Care 2007; 11: R38.

40 Latour-Perez J, Alcala-Lopez A, Garcia-Garcia MA, et al. Diagnostic accuracy of sTREM-1 to identify infection in critically ill patients with systemic inflammatory response syndrome. Clin Biochem 2010; 43: $720-24$

41 Meynaar IA, Droog W, Batstra M, Vreede R, Herbrink P. In critically ill patients, serum procalcitonin is more useful in In critically ill patients, serum procalcitonin is more useful in
differentiating between sepsis and SIRS than CRP, Il-6, or LBP. differentiating between sepsis and Ses Pract 2011; 2011: 594645.

42 Naeini AE, Montazerolghaem S. Procalcitonin marker for sepsis diagnosis. Evaluating a rapid immuno-chromatografic test Saudi Med J 2006; 27: 422-24

43 Oshita H, Sakurai J, Kamitsuna M. Semi-quantitative procalcitonin test for the diagnosis of bacterial infection: clinical use and experience in Japan. J Microbiol Immunol Infect 2010; 43: 222-27.

44 Pavcnik-Arnol M, Hojker S, Derganc M. Lipopolysaccharide binding protein, lipopolysaccharide, and soluble CD14 in sepsis of
critically ill neonates and children. Intensive Care Med 2007; 33: $1025-32$

45 Ruiz-Alvarez MJ, Garcia-Valdecasas S, De Pablo R, et al. Diagnostic efficacy and prognostic value of serum procalcitonin concentration in patients with suspected sepsis. J Intensive Care Med 2009; 24: 63-71

46 Sakr Y, Burgett U, Nacul FE, Reinhart K, Brunkhorst F. Lipopolysaccharide binding protein in a surgical intensive care unit: a marker of sepsis? Crit Care Med 2008: 36: 2014-22.
47 Selberg O, Hecker H, Martin M, Klos A, Bautsch W, Kohl J. Discrimination of sepsis and systemic inflammatory response syndrome by determination of circulating plasma concentrations of procalcitonin, protein complement 3a, and interleukin-6. Crit Care Med 2000; 28: 2793-98.

48 Simon L, Saint-Louis P, Amre DK, Lacroix J, Gauvin F. Procalcitonin and C-reactive protein as markers of bacterial infection in critically ill children at onset of systemic inflammatory response syndrome. Pediatr Crit Care Med 2008; 9: 407-13.

49 Suprin E, Camus C, Gacouin A, et al. Procalcitonin: a valuable indicator of infection in a medical ICU? Intensive Care Med 2000; 26: $1232-38$.

50 Tsalik EL, Jaggers LB, Glickman SW, et al. Discriminative value of inflammatory biomarkers for suspected sepsis. J Emerg Med 2012; 43: 97-106.

51 Tsangaris I, Plachouras D, Kavatha D, et al. Diagnostic an prognostic value of procalcitonin among febrile critically ill patients with prolonged ICU stay, BMC Infect Dis 2009; 9: 213

52 Tugrul S, Esen F, Celebi S, et al. Reliability of procalcitonin as a severity marker in critically ill patients with inflammatory response.

53 Wanner GA, Keel M, Steckholzer U, Beier W, Stocker R, Ertel W. Relationship between procalcitonin plasma levels and severity of injury, sepsis, organ failure, and mortality in injured patients. Crit Care Med 2000; 28: 950-57.

54 Aouifi A, Piriou V, Bastien O, et al. Usefulness of procalcitonin for diagnosis of infection in cardiac surgical patients. Crit Care Med 2000; 28: 3171-76.

55 Brunkhorst FM, Wegscheider K, Forycki ZF, Brunkhorst R. Procalcitonin for early diagnosis and differentiation of SIRS, sepsis, evere sepsis, and septic shock, Intensive Care Med 2000; 26 (suppl 2): S148-52.

56 Baumgarten R, Pequeriaux NCV, Van Puyenbroek MJE, Speelberg B. Diagnosis of sepsis by procalcitonin. Nederlands Tijdschrift voor de Klinische Chemie 2002; 27: 32-35 (in Dutch)

57 Chan YL, Tseng CP, Tsay PK, Chang SS, Chiu TF, Chen JC. Procalcitonin as a marker of bacterial infection in the emergency department: an observational study. Crit Care 2004; 8: R12-20.

58 Cheval C, Timsit JF, Garrouste-Orgeas M, et al. Procalcitonin (PCT) is useful in predicting the bacterial origin of an acute circulatory failure in critically ill patients. Intensive Care Med 2000; 26 (suppl 2): S153-58.

59 Clec'h C, Ferriere F, Karoubi P, et al. Diagnostic and prognostic value of procalcitonin in patients with septic shock. Crit Care Med 2004; 32: 1166-69.

60 Geppert A, Steiner A, Delle-Karth G, Heinz G, Huber K. Usefulness of procalcitonin for diagnosing complicating sepsis in patients with cardiogenic shock. Intensive Care Med 2003; 29: 1384-89.

61 Giamarellos-Bourboulis EJ, Mega A, Grecka P, et al. Procalcitonin: a marker to clearly differentiate systemic inflammatory response syndrome and sepsis in the critically ill patient? Intensive Care Med 2002. 28: 1351-56.

62 Hensler T, Sauerland S, Lefering R, et al. The clinical value of procalcitonin and neopterin in predicting sepsis and organ failure after major trauma. Shock 2003; 20: 420-46.

63 Mokart D, Merlin M, Sannini A, et al. Procalcitonin, interleukin 6 and systemic inflammatory response syndrome (SIRS): early markers of postoperative sepsis after major surgery. BrJ Anaesth 2005; 94: 767-73.

64 Rothenburger M, Markewitz A, Lenz T, et al. Detection of acute phase response and infection. The role of procalcitonin and C-reactive protein. Clin Chem Lab Med 1999; 37: 275-79.

65 Ruokonen E, Ilkka L, Niskanen M, Takala J. Procalcitonin and neopterin as indicators of infection in critically ill patients. Acta Anaesthesiol Scand 2002; 46: 398-404.

66 Ugarte H, Silva E, Mercan D, De Mendonca A, Vincent JL. Procalcitonin used as a marker of infection in the intensive care unit. Crit Care Med 1999; 27: 498-504.

67 Bossink AW, Groeneveld AB, Thijs LG. Prediction of microbia infection and mortality in medical patients with fever: plasma procalcitonin, neutrophilic elastase-alpha1-antitrypsin, and lactoferrin compared with clinical variables. Clin Infect Dis 1999; 29: 398-407. 
68 Hausfater P, Garric S, Ayed SB, Rosenheim M, Bernard M, Riou B. Usefulness of procalcitonin as a marker of systemic infection in emergency department patients: a prospective study. Clin Infect Dis 2002; 34: 895-901

69 Meisner M, Rauschmayer C, Schmidt J, et al. Early increase of procalcitonin after cardiovascular surgery in patients with postoperative complications. Intensive Care Med 2002; 28: 1094-102.

70 Balc IC, Sungurtekin H, Gurses E, Sungurtekin U, Kaptanoglu B. Usefulness of procalcitonin for diagnosis of sepsis in the intensiv care unit. Crit Care 2003; 7: 85-90.

71 Benoist JF, Mimoz O, Assicot M, Edouard A. Serum procalcitonin but not C-reactive protein, identifies sepsis in trauma patients. Clin Chem 1998; 44: 1778-79.

72 de Talancé N, Claudel C, Burlet C. La procalcitonine (PCT) est-elle le marqueur spécifique du choc septique? Immuno-analyse ą Biologie Spécialisée 2003; 18: 120-22

73 Luzzani A, Polati E, Dorizzi R, Rungatscher A, Pavan R, Merlini A. Comparison of procalcitonin and C-reactive protein as markers of 2003; 31: 1737-41.

74 Oberhoffer M, Karzai W, Meier-Hellmann A, Bogel D, Fassbinder J, Reinhart K. Sensitivity and specificity of various markers of inflammation for the prediction of tumor necrosis factor-alpha and interleukin-6 in patients with sepsis. Crit Care Med 1999; 27: 1814-18.

75 Muller B, Becker KL, Schachinger H, et al. Calcitonin precursors are reliable markers of sepsis in a medical intensive care unit. Crit Care Med 2000; 28: 977-83.
76 Dorge H, Schondube FA, Dorge P, Seipelt R, Voss M, Messmer BJ. Procalcitonin is a valuable prognostic marker in cardiac surgery but not specific for infection. Thorac Cardiovasc Surg 2003; 51: 322-26.

77 Whiting P, Rutjes AW, Reitsma JB, Glas AS, Bossuyt PM,

Kleijnen J. Sources of variation and bias in studies of diagnostic accuracy: a systematic review. Ann Intern Med 2004; 140: 189-202.

78 Bossuyt PM, Reitsma JB, Bruns DE, et al. Towards complete and accurate reporting of studies of diagnostic accuracy: the STARD Prof 210

79 Schuetz P, Chiappa V, Briel M, Greenwald JL. Procalcitonin algorithms for antibiotic therapy decisions. a systematic review of randomized controlled trials and recommendations for clinical algorithms. Arch Intern Med 2011; 171: 1322-31.

80 Schuetz P, Briel M, Christ-Crain M, et al. Procalcitonin to guide initiation and duration of antibiotic treatment in acute respiratory infections: an individual patient data meta-analysis. Clin Infect Dis 2012; 55: 651-62.

81 Fischer JE, Bachmann LM, Jaeschke R. A readers' guide to the interpretation of diagnostic test properties: clinical example of sepsis. Intensive Care Med 2003, 29: 1043-51.

82 Backes Y, van der Sluijs KF, Mackie DP et al. Usefulness of suPAR as a biological marker in patients with systemic inflammation or infection: a systematic review. Intensive Care Med 2012; 38: 1418-28. 


\section{Diskussion}

Ziel dieser Metaanalyse war es, zu klären, ob Procalcitonin in der Lage ist, zwischen septischen Patienten und solchen mit einer systemischen Entzündungsreaktion nichtbakteriellen Ursprungs zu unterscheiden.

In der Vergangenheit gab es zwei Metaanalysen, die dasselbe Ziel verfolgten (Tang et al. 2007, Uzzan et al. 2006). Diese kamen jedoch zu unterschiedlichen Ergebnissen.

Uzzan und Kollegen (Uzzan et al. 2006) veröffentlichten 2006 ihre Ergebnisse. Sie schlossen Studien ein, die zwischen April 1996 und Oktober 2004 zum Thema veröffentlicht wurden und fanden heraus, dass die summery receiver operating characteristic curve für die Diagnose der Sepsis bei kritisch kranken Patienten für Procalcitonin besser war als die für das Creaktive Protein, welches bis dato herkömmlich in der Praxis genutzt wurde. Allerdings beschränkten die Untersucher die eingeschlossene Population auf chirurgische und unfallchirurgische Patienten. Dies macht es unmöglich die Ergebnisse auf andere, z.B. internistische Patienten, zu übertragen. Außerdem wurden keine weiteren Untersuchungen bezüglich der Heterogenität durchgeführt, z.B. hinsichtlich des Patientensettings, des Infektfokus oder anderer studienspezifischer Kovariaten.

In einer anderen Metaanalyse aus dem Jahr 2007 schlossen Tang und Kollegen (Tang et al. 2007) 18 Studien ein, welche zwischen April 1996 und November 2005 veröffentlicht wurden. Sie resümierten, dass Procalcitonin nicht in der Lage wäre, zwischen Sepsis und SIRS zu unterscheiden. Laut den errechneten Werten war der diagnostische Nutzen von PCT gering: die Gesamtsensitivität und -spezifität betrug 71\% (95\% CI 67-76). Die Area under the summary receiver operating characteristic curve war 0,78 (95/ CI 0,73-0,83).

Diese eher enttäuschenden Ergebnisse wurden jedoch stark von den vorher festgelegten Einschlusskriterien beeinflusst. Zum einen wurden Studien ausgeschlossen, die Patienten mit für Sepsis typischen Infektfoki untersuchten, z.B. solche mit Meningitis oder abdomineller Sepsis. Zum anderen wurden Studien ebenfalls nicht berücksichtigt, wenn sie die Fähigkeit von PCT untersuchten, einen septischen Schock zu diagnostizieren. Da die Progression von Sepsis zum septischen Schock immer auch mit einem Anstieg der Procalcitoninkonzentration im Blut verbunden ist, bedeutet ein Ausschluss solcher Patienten mit einer hohen Wahrscheinlichkeit eine Unterbewertung des Gesamtschätzers für die diagnostische Genauigkeit. Um solch eine systematische Verzerrung zu vermeiden, schlossen wir alle verfügbaren Studien ein, welche die diagnostische Wertigkeit von PCT bei jeglichen 
septischen Zuständen untersuchten - Sepsis, schwerer Sepsis und dem septischen Schock. Des Weiteren könnte die eben erwähnte systematische Verzerrung des gepoolten Gesamtschätzers noch davon verstärkt worden sein, dass teils Studien eingeschlossen wurden, welche Patienten untersuchten, die nicht kritisch krank waren bzw. keine SIRS hatten.

Insgesamt schlossen wir 23 Studien aus unserer Untersuchung aus, welche von den oben genannten Metaanalysen eingeschlossen wurden (siehe publizierte Originalarbeit). Bei dreizehn von ihnen bestand die Kontrollgruppe aus gesunden Menschen bzw. aus Patienten, die nicht kritisch krank waren oder unter einer SIRS litten. Sieben schlossen Patienten ein, die eine Infektion ohne systemische Entzündungsreaktion hatten oder gaben keine genaue Definition für den zugrunde liegenden Zustand. Beides war nicht mit unseren Einschlusskriterien vereinbar. Außerdem gaben vier Studien nur unzureichende Informationen, um eine $2 \times 2$ Kontingenztafel $\mathrm{zu}$ erstellen. Eine untersuchte den prädiktiven Wert von Procalcitonin für Tumornekrosefaktor $\alpha$ - und Interleukin 6-Konzentrationen. Eine andere führte bei einigen Patienten multiple Messungen durch und eine Studie untersuchte den prognostischen Nutzen von PCT für Infektionen nach einem Herzinfarkt.

Die Metaanalyse von Tang und Kollegen weist jedoch nicht nur Mängel bei den Einschlusskriterien auf, sondern auch bei der quantitativen Datenanalyse. Sensitivität und Spezifität werden zu einem einzelnen Wert für den diagnostischen Nutzen zusammengefasst. Hierdurch gehen natürlich wichtige Informationen verloren. Um den zweidimensionalen Charakter zu erhalten, nutzten wir zur Berechnung des gepoolten Gesamtschätzers das bivariate mixed-effects regression model von van Houwellingen (Van Houwelingen et al. 1993, van Houwelingen et al. 2002).

Aber auch unsere Metaanalyse weist einige Limitationen auf (Whiting et al. 2004).

Zum ersten fanden wir eine erhebliche Heterogenität zwischen den einzelnen Studien $\left(\mathrm{I}^{2}=96 \%, 95 \%\right.$ CI 94-99). Diese unterschieden sich in vielen verschiedenen Punkten, z.B. im klinischen Spektrum der Patienten, dem Aufnahmemodus, dem Procalcitonintest, welcher verwendet wurde (siehe Appendix 1) usw., aber auch in der methodischen Qualität gab es deutliche Unterschiede. Keine der mittels Meta-Regression untersuchten Studiencharakteristika konnte jedoch für die festgestellte Heterogenität verantwortlich gemacht werden. Wahrscheinlich ist, dass weitere, nicht extrahierte Unterschiede zwischen den Studien ebenfalls zu diesem Problem beitragen. Durch die Untersuchung einer homogeneren Population könnte diese Schwierigkeit natürlich gelöst bzw. zumindest gemindert werden. Allerdings würde dies wiederum zu einem Selektionsbias führen. 
Die zweite wichtige Limitation unserer Studie ist, dass es bis heute immer noch keinen reliablen Test zum Nachweis einer Infektion gibt. Dies bedeutet, dass klinische Studien immer auch durch die Wahl ihres Goldstandards eine gewisse Verzerrung erfahren. Gemäß unseren Einschlusskriterien musste das Vorliegen einer Infektion entweder mikrobiologisch nachgewiesen oder zumindest klinisch vermutet sein. Alle, der von uns eingeschlossenen Studien, erfüllten diese Anforderung (siehe Appendix 2, 3 und 4). Allerdings machten die meisten keine exakten Angaben darüber, wie die festgestellte Infektion nachgewiesen wurde. In Abhängigkeit von einer im Vorfeld durchgeführten Antibiotikatherapie gelingt der Nachweis einer Bakteriämie mittels Blutkultur nur in ca. 30\% der Patienten mit Sepsis (Bates et al. 1990, Bates et al. 1997). Dazu kommt noch die fehlende Standardisierung von klinischen und radiologischen Untersuchungen, weshalb unterschiedliche Untersucher häufig auch zu unterschiedlichen Ergebnissen bezüglich des klinischen Zustandes eines Patienten kommen. Dieses Phänomen nennt sich Interobserver-Variabilität und führt unter Umständen zu falsch-negativen bzw. falsch-positiven Bewertungen des Krankheitszustandes. Wie oben erwähnt, schlossen wir ausschließlich Studien ein, die über einen gut definierten Referenzstandard die Diagnose der Sepsis betreffend verfügten. Nichtsdestotrotz wissen wir natürlich nicht mit hundert prozentiger Sicherheit, ob auch alle Patienten mit Sepsis als solche erkannt wurden.

Drittens wurde die Durchführung von einigen Studien nur sehr mangelhaft beschrieben. Vor allem in Bezug auf nicht interpretierbare oder intermediäre Ergebnisse beim PCT-Test und bezüglich des Test-Review-Bias (siehe Appendix 2, 3 und 4) gaben die Mehrheit der Studien nur ungenügende Informationen über ihr Vorgehen. Um die daraus resultierende Verzerrung der Ergebnisse zu minimieren und mehr Homogenität $\mathrm{zu}$ schaffen, empfehlen wir Untersuchern zur besseren Nachvollziehbarkeit ihres Vorgehens die „Standards for Reporting of Diagnostic Accuracy-Checkliste“ (Bossuyt et al. 2004) zu verwenden (siehe Appendix 5). Auch der Einsatz der „Quality Assessment of Diagnostic Accuracy Studies (QUADAS)Checkliste“" (Whiting et al. 2003) wäre möglich.

Viertens konnte mittels Deeks' funnel plot asymmetry Test Publikationsbias nachgewiesen werden $(18,57 ; \mathrm{P}=0,00)$ (Deeks et al. 2005) (siehe Appendix 6). Studien mit wünschenswerteren Ergebnissen haben natürlich eine bessere Chance veröffentlich zu werden, als solche deren Ergebnisse wenig gewinnbringend und ohne großen wissenschaftlichen Erkenntnisgewinn sind. Da wir nur Studien einschlossen, welche auch in Datenbanken oder anderweitig veröffentlicht wurden, führt diese Verzerrung letzten Endes wahrscheinlich zu einer Überschätzung des diagnostischen Nutzens. Um dieses Problem 
weitgehend zu lösen, durchsuchten zwei voneinander unabhängige Untersucher erneut die Datenbanken und die Quellenangaben der Primärstudien nach neuen, noch nicht berücksichtigten Studien. Leider konnten keine weiteren relevanten Publikationen identifiziert werden.

Schlussendlich, schlossen wir außerdem nur Veröffentlichungen ein, welche auf Deutsch, Englisch oder Französisch publiziert wurden. Auch dies könnte unsere Ergebnisse beeinflusst haben.

Ein weiteres ungelöstes Problem stellt die Festlegung eines einheitlichen Cutoff-Wertes dar, welcher an Sepsis erkrankte Patienten von solchen unterscheidet, die lediglich an einem SIRS leiden. Insgesamt konnte ein sog. „Thresholdeffekt“ ausgeschlossen werden, d.h. der Anteil der Heterogenität, welcher sich durch die verschiedenen Cutoff-Werte erklärt, war insgesamt eher gering (0,05). Nichtsdestotrotz variierten die Cutoff-Werte zwischen den eingeschlossenen Studien erheblich. Einige legten den Grenzwert so, dass die besten Ergebnisse für Sensitivität und Spezifität erzielt wurden. Andere gaben diese beiden für verschiedene Cutoff-Werte an. Das Problem hierbei ist, dass die festgelegten Grenzwerte im Nachhinein nicht im klinischen Alltag validiert worden sind. Die Größen der diagnostischen Wertigkeit eines Markers korrelieren negativ miteinander. Die Veränderung des CutoffWerts bedeutet gleichzeitig die Sensitivität auf Kosten der Spezifität zu ändern und umgekehrt. Bei einer schwerwiegenden Erkrankung wie der Sepsis wäre es fatal, falschnegative Ergebnisse zu akzeptieren und somit schwer kranken Menschen eine suffiziente Therapie zu verwehren (Garnacho-Montero et al. 2008). Auf der anderen Seite sollten, um der Entstehung von Resistenzen auf Antibiotika vorzubeugen, eventuelle Nebenwirkungen zu minimieren und Kosten zu sparen, kritisch kranke Patienten ohne Nachweis einer bakteriellen Infektion auch als solche erkannt werden, d.h. die Zahl der falsch-positiven sollte ebenfalls möglichst gering gehalten werden. Aus dieser Problematik heraus ergibt sich, dass ein sinnvoller Grenzwert zur Unterscheidung zwischen SIRS und Sepsis gefunden werden muss. Wir empfehlen daher verschiedene Phasen in der Untersuchung der diagnostischen Wertigkeit eines Markers. In einem ersten Schritt sollten Forscher den Nutzen eines Marker an einer ausgewählten Gruppe von Patienten eruieren, um einen angebrachten Cutoff-Wert zu finden. In einem zweiten sollte der gefundene Grenzwert dann mittels einer diagnostischen, kontrollierten Studie auf seine Tauglichkeit für die tägliche klinische Routine untersucht werden. 
Der mittlere Cutoff-Wert der eingeschlossenen Studien unserer Metaanalyse betrug 1,1 ng/ml (IQR 0,5-2,0). Die Abwesenheit eines Tresholdeffektes lässt darauf schließen, dass ein Grenzwert zwischen 1,0 und 2,0 sinnvoll für die Diagnose der Sepsis bei kritisch kranken Patienten ist. Dies findet sich auch im Einklang mit den Empfehlungen jüngst durchgeführter Studien zur Therapieentscheidung anhand des PCTs (Prkno et al. 2013, Schuetz et al. 2011, Schuetz et al. 2012).

Der größte Nutzen eines diagnostischen Markers ist es, klinische Entscheidungen nach ihm zu treffen und somit ein besseres Outcome $\mathrm{zu}$ erzielen, Kosten $\mathrm{zu}$ sparen sowie möglichen Resistenzen und Nebenwirkungen vorzubeugen.

Aus unserer Metaanalyse ergeben sich wichtige Informationen für kritisch kranke Patienten, für welche eine Entscheidungsfindung anhand diagnostischer Marker von höchstem Interesse ist. Neben der Sensitivität und der Spezifität stellen der Likelihood Ratio und die Posttestwahrscheinlichkeit relevante Informationen für Kliniker dar.

Der positive Likelihoodquotient ( $\mathrm{LR}+)$ gibt an, wie viel Mal wahrscheinlicher ein positives Testergebnis bei Kranken eintritt als bei Gesunden. Er kann folgendermaßen beschrieben werden: $\quad$ LR $+=$ Sensitivität/ (1-Spezifität). Im Gegensatz dazu steht der negative Likelihoodquotient (LR-), welcher angibt wie viel Mal wahrscheinlicher ein negatives Testergebnis bei Kranken eintritt als bei Gesunden. Er wird wie folgt definiert: LR- = (1Sensitivität) / Spezifität.

Mithilfe der Likelihoodquotienten und der Prätestwahrscheinlichkeit lässt sich die Posttestwahrscheinlichkeit ermitteln. Die Prätestwahrscheinlichkeit gibt die Wahrscheinlichkeit an, dass eine Erkrankung vorliegt, noch bevor ein klinischer Test zur Verifizierung durchgeführt wurde. Sie ergibt sich unter anderem aus der Prävalenz für eine gewisse Altersgruppe, anamnestischen Daten und klinischen Symptomen. Davon zu unterscheiden, ist die Posttestwahrscheinlichkeit. Diese sagt aus, wie wahrscheinlich das Vorhandensein einer Erkrankung nach Vorliegen des Testergebnisses, unter Berücksichtigung der Prätestwahrscheinlichkeit, ist.

Die Posttestwahrscheinlichkeit lässt sich anhand eines Fagan-Nomogramms ablesen, welches auch im Rahmen unserer Metaanalyse erstellt wurde (siehe publizierte Originalarbeit). Laut unserer Berechnungen waren sowohl die ermittelten Likelihoodquotienten als auch die Posttestwahrscheinlichkeit moderat.

Der positive Likelihoodquotient betrug 4. Das bedeutet, dass eine Person mit Sepsis eine viermal höhere Chance hat, ein positives Testergebnis zu erhalten als eine Person mit SIRS. 
Bei einer angenommenen Prätestwahrscheinlichkeit von 20\% ergibt sich bei positivem Testergebnis eine Posttestwahrscheinlichkeit 48\%. Der negative Likelihoodquotient andererseits betrug 0,29. Hieraus resultiert laut Fagan-Nomogramm bei negativem Testergebnis eine Posttestwahrscheinlichkeit von 7\%.

Natürlich wurden diese Größen aus dichotomisierten Daten errechnet. So ist das Ergebnis des Procalcitonintests entweder negativ oder positiv. Das Problem einer solchen Zweidimensionalität ist, dass wichtige Information verloren geht (Fischer et al. 2003). Aufgrund der Tatsache, dass die Procalcitoninkonzentration mit der Schwere der Krankheit steigt (Assicot et al. 1993, Brunkhorst et al. 2000, Christ-Crain und Muller 2005), haben natürlich Patienten mit hoher nachgewiesener Konzentration auch eine höhere Wahrscheinlichkeit an einer Sepsis erkrankt zu sein als solche, mit einer niedrigen nachgewiesenen Konzentration. Um diesen Informationsverlust leicht einzudämmen und präzisere Auskunft über die Zuverlässigkeit eines diagnostischen Tests zu geben, empfehlen wir, Likelihood Ratios auf verschiedenen Cutoff-Werten basierend, zu errechnen. 


\section{Schlussfolgerungen}

Die Ergebnisse unserer Untersuchung zeigen, dass Procalcitonin ein hilfreicher Marker für die frühzeitige Diagnose der Sepsis bei kritisch kranken Patienten ist. Nichtsdestotrotz ist auch Procalcitonin kein perfekter Marker und sollte nicht uneingeschränkt als alleiniger und endgültiger Test verwendet werden, sondern immer in Zusammenhang mit Anamnese, klinischer Untersuchung und, wenn möglich, mit mikrobiologischen Ergebnissen interpretiert werden. Letzten Endes gibt es den idealen Marker aber auch nicht. Sepsis ist kein spezifisches Syndrom sondern ein pathophysiologischer Prozess und daher zu komplex, um von einem einzelnen Messwert beschrieben zu werden.

Dennoch stellt Procalcitonin bis dato einen der vielversprechendsten Marker für die Diagnose der Sepsis bei schwer kranken Menschen dar. Einige andere Moleküle und Mediatoren, welche als Antwort auf eine Infektion frei gesetzt werden, wurden in der Vergangenheit ebenfalls untersucht, z.B. CRP, soluble TREM1, IL-6, IL-8 und soluble PLAUR, jedoch ohne herausragendes Ergebnis (Backes et al. 2012, Harbarth et al. 2001, Latour-Perez et al. 2010, Simon et al. 2004).

Des Weiteren empfiehlt sich zur Beurteilung der Schwere der Erkrankung und des Krankheitsverlaufs die kontinuierliche Re-Evaluierung. 


\section{Literatur- und Quellenverzeichnis}

Angus DC, Linde-Zwirble WT, Lidicker J, Clermont G, Carcillo J, Pinsky MR. 2001.

Epidemiology of severe sepsis in the United States: analysis of incidence, outcome, and associated costs of care. Crit Care Med, 29 (7):1303-1310.

Assicot M, Gendrel D, Carsin H, Raymond J, Guilbaud J, Bohuon C. 1993. High serum procalcitonin concentrations in patients with sepsis and infection. Lancet, 341 (8844):515-518.

Backes Y, van der Sluijs KF, Mackie DP, Tacke F, Koch A, Tenhunen JJ, Schultz MJ. 2012. Usefulness of suPAR as a biological marker in patients with systemic inflammation or infection: a systematic review. Intensive Care Med, 38 (9):1418-1428.

Bates DW, Cook EF, Goldman L, Lee TH. 1990. Predicting bacteremia in hospitalized patients. A prospectively validated model. Ann Intern Med, 113 (7):495-500.

Bates DW, Sands K, Miller E, Lanken PN, Hibberd PL, Graman PS, Schwartz JS, Kahn K, Snydman DR, Parsonnet J, Moore R, Black E, Johnson BL, Jha A, Platt R. 1997. Predicting bacteremia in patients with sepsis syndrome. Academic Medical Center Consortium Sepsis Project Working Group. J Infect Dis, 176 (6):1538-1551.

Bauer M, Brunkhorst F, Welte T, Gerlach H, Reinhart K. 2006. [Sepsis. Update on pathophysiology, diagnostics and therapy]. Anaesthesist, 55 (8):835-845.

Becker KL, Snider R, Nylen ES. 2010. Procalcitonin in sepsis and systemic inflammation: a harmful biomarker and a therapeutic target. Br J Pharmacol, 159 (2):253-264.

Bernard GR, Vincent JL, Laterre PF, LaRosa SP, Dhainaut JF, Lopez-Rodriguez A, Steingrub JS, Garber GE, Helterbrand JD, Ely EW, Fisher CJ, Jr. 2001. Efficacy and safety of recombinant human activated protein C for severe sepsis. N Engl J Med, 344 (10):699709.

Bone RC, Balk RA, Cerra FB, Dellinger RP, Fein AM, Knaus WA, Schein RM, Sibbald WJ. 2009. Definitions for sepsis and organ failure and guidelines for the use of innovative therapies in sepsis. The ACCP/SCCM Consensus Conference Committee. American College of Chest Physicians/Society of Critical Care Medicine. 1992. Chest, 136 (5 Suppl):e28.

Bossuyt PM, Reitsma JB, Bruns DE, Gatsonis CA, Glasziou PP, Irwig LM, Lijmer JG, Moher D, Rennie D, de Vet HC. 2004. Towards complete and accurate reporting of studies of diagnostic accuracy: the STARD initiative. Fam Pract, 21 (1):4-10. 
Brunkhorst FM. 2006. [Epidemiology, economy and practice -- results of the German study on prevalence by the competence network sepsis (SepNet)]. Anasthesiol Intensivmed Notfallmed Schmerzther, 41 (1):43-44.

Brunkhorst FM, Wegscheider K, Forycki ZF, Brunkhorst R. 2000. Procalcitonin for early diagnosis and differentiation of SIRS, sepsis, severe sepsis, and septic shock. Intensive Care Med, 26 Suppl 2:S148-152.

Chaudhry H, Zhou J, Zhong Y, Ali MM, McGuire F, Nagarkatti PS, Nagarkatti M. 2013. Role of Cytokines as a Double-edged Sword in Sepsis. In Vivo, 27 (6):669-684.

Christ-Crain M, Muller B. 2005. Procalcitonin in bacterial infections--hype, hope, more or less? Swiss Med Wkly, 135 (31-32):451-460.

Cohen J. 2002. The immunopathogenesis of sepsis. Nature, 420 (6917):885-891.

Dandona P, Nix D, Wilson MF, Aljada A, Love J, Assicot M, Bohuon C. 1994. Procalcitonin increase after endotoxin injection in normal subjects. J Clin Endocrinol Metab, 79 (6):1605-1608.

Deeks JJ, Macaskill P, Irwig L. 2005. The performance of tests of publication bias and other sample size effects in systematic reviews of diagnostic test accuracy was assessed. $\mathrm{J}$ Clin Epidemiol, 58 (9):882-893.

Engel C, Brunkhorst FM, Bone HG, Brunkhorst R, Gerlach H, Grond S, Gruendling M, Huhle G, Jaschinski U, John S, Mayer K, Oppert M, Olthoff D, Quintel M, Ragaller M, Rossaint R, Stuber F, Weiler N, Welte T, Bogatsch H, Hartog C, Loeffler M, Reinhart K. 2007. Epidemiology of sepsis in Germany: results from a national prospective multicenter study. Intensive Care Med, 33 (4):606-618.

Fischer JE, Bachmann LM, Jaeschke R. 2003. A readers' guide to the interpretation of diagnostic test properties: clinical example of sepsis. Intensive Care Med, 29 (7):10431051.

Garnacho-Montero J, Ortiz-Leyba C, Herrera-Melero I, Aldabo-Pallas T, Cayuela-Dominguez A, Marquez-Vacaro JA, Carbajal-Guerrero J, Garcia-Garmendia JL. 2008. Mortality and morbidity attributable to inadequate empirical antimicrobial therapy in patients admitted to the ICU with sepsis: a matched cohort study. J Antimicrob Chemother, 61 (2):436-441.

Gendrel D, Raymond J, Coste J, Moulin F, Lorrot M, Guerin S, Ravilly S, Lefevre H, Royer C, Lacombe C, Palmer P, Bohuon C. 1999. Comparison of procalcitonin with Creactive protein, interleukin 6 and interferon-alpha for differentiation of bacterial vs. viral infections. Pediatr Infect Dis J, 18 (10):875-881. 
Gogos CA, Drosou E, Bassaris HP, Skoutelis A. 2000. Pro- versus anti-inflammatory cytokine profile in patients with severe sepsis: a marker for prognosis and future therapeutic options. J Infect Dis, 181 (1):176-180.

Harbarth S, Holeckova K, Froidevaux C, Pittet D, Ricou B, Grau GE, Vadas L, Pugin J. 2001. Diagnostic value of procalcitonin, interleukin-6, and interleukin-8 in critically ill patients admitted with suspected sepsis. Am J Respir Crit Care Med, 164 (3):396-402. Hatherill M, Tibby SM, Sykes K, Turner C, Murdoch IA. 1999. Diagnostic markers of infection: comparison of procalcitonin with $\mathrm{C}$ reactive protein and leucocyte count. Arch Dis Child, 81 (5):417-421.

Latour-Perez J, Alcala-Lopez A, Garcia-Garcia MA, Sanchez-Hernandez JF, Abad-Terrado C, Viedma-Contreras JA, Masia M, Gonzalez-Tejera M, Arizo-Leon D, Porcar MJ, Bonilla-Rovira F, Gutierrez F. 2010. Diagnostic accuracy of sTREM-1 to identify infection in critically ill patients with systemic inflammatory response syndrome. Clin Biochem, 43 (9):720-724.

Marshall JC, Reinhart K. 2009. Biomarkers of sepsis. Crit Care Med, 37 (7):2290-2298.

Martin GS, Mannino DM, Eaton S, Moss M. 2003. The epidemiology of sepsis in the United States from 1979 through 2000. N Engl J Med, 348 (16):1546-1554.

Meisner M. 2002. Pathobiochemistry and clinical use of procalcitonin. Clin Chim Acta, 323 (1-2):17-29.

Muller B, Becker KL. 2001. Procalcitonin: how a hormone became a marker and mediator of sepsis. Swiss Med Wkly, 131 (41-42):595-602.

Pittet D, Rangel-Frausto S, Li N, Tarara D, Costigan M, Rempe L, Jebson P, Wenzel RP. 1995. Systemic inflammatory response syndrome, sepsis, severe sepsis and septic shock: incidence, morbidities and outcomes in surgical ICU patients. Intensive Care Med, 21 (4):302-309.

Prkno A, Wacker C, Brunkhorst FM, Schlattmann P. 2013. Procalcitonin-guided therapy in intensive care unit patients with severe sepsis and septic shock--a systematic review and meta-analysis. Crit Care, 17 (6):R291.

Reinhart K, Meisner M, Brunkhorst FM. 2006. Markers for sepsis diagnosis: what is useful? Crit Care Clin, 22 (3):503-519, ix-x.

Reinhart K, Brunkhorst FM, Bone HG, Bardutzky J, Dempfle CE, Forst H, Gastmeier P, Gerlach H, Grundling M, John S, Kern W, Kreymann G, Kruger W, Kujath P, Marggraf G, Martin J, Mayer K, Meier-Hellmann A, Oppert M, Putensen C, Quintel M, Ragaller M, Rossaint R, Seifert H, Spies C, Stuber F, Weiler N, Weimann A, 
Werdan K, Welte T. 2010. [Prevention, diagnosis, treatment, and follow-up care of sepsis. First revision of the S2k Guidelines of the German Sepsis Society (DSG) and the German Interdisciplinary Association for Intensive and Emergency Care Medicine (DIVI)]. Anaesthesist, 59 (4):347-370.

Rivers E, Nguyen B, Havstad S, Ressler J, Muzzin A, Knoblich B, Peterson E, Tomlanovich M. 2001. Early goal-directed therapy in the treatment of severe sepsis and septic shock. N Engl J Med, 345 (19):1368-1377.

Schuetz P, Chiappa V, Briel M, Greenwald JL. 2011. Procalcitonin algorithms for antibiotic therapy decisions: a systematic review of randomized controlled trials and recommendations for clinical algorithms. Arch Intern Med, 171 (15):1322-1331.

Schuetz P, Briel M, Christ-Crain M, Stolz D, Bouadma L, Wolff M, Luyt CE, Chastre J, Tubach F, Kristoffersen KB, Wei L, Burkhardt O, Welte T, Schroeder S, Nobre V, Tamm M, Bhatnagar N, Bucher HC, Mueller B. 2012. Procalcitonin to guide initiation and duration of antibiotic treatment in acute respiratory infections: an individual patient data meta-analysis. Clin Infect Dis, 55 (5):651-662.

Simon L, Gauvin F, Amre DK, Saint-Louis P, Lacroix J. 2004. Serum procalcitonin and Creactive protein levels as markers of bacterial infection: a systematic review and metaanalysis. Clin Infect Dis, 39 (2):206-217.

Tang BM, Eslick GD, Craig JC, McLean AS. 2007. Accuracy of procalcitonin for sepsis diagnosis in critically ill patients: systematic review and meta-analysis. Lancet Infect Dis, 7 (3):210-217.

Uzzan B, Cohen R, Nicolas P, Cucherat M, Perret GY. 2006. Procalcitonin as a diagnostic test for sepsis in critically ill adults and after surgery or trauma: a systematic review and meta-analysis. Crit Care Med, 34 (7):1996-2003.

Van Houwelingen HC, Zwinderman KH, Stijnen T. 1993. A bivariate approach to metaanalysis. Stat Med, 12 (24):2273-2284.

van Houwelingen HC, Arends LR, Stijnen T. 2002. Advanced methods in meta-analysis: multivariate approach and meta-regression. Stat Med, 21 (4):589-624.

Villar J, Maca-Meyer N, Perez-Mendez L, Flores C. 2004. Bench-to-bedside review: understanding genetic predisposition to sepsis. Crit Care, 8 (3):180-189.

Whiting P, Rutjes AW, Reitsma JB, Bossuyt PM, Kleijnen J. 2003. The development of QUADAS: a tool for the quality assessment of studies of diagnostic accuracy included in systematic reviews. BMC Med Res Methodol, 3:25. 
Whiting P, Rutjes AW, Reitsma JB, Glas AS, Bossuyt PM, Kleijnen J. 2004. Sources of variation and bias in studies of diagnostic accuracy: a systematic review. Ann Intern Med, 140 (3):189-202. 


\section{Anhang}

\section{Appendix 1: Assay characteristics}

(http://www.procalcitonin.com/default.aspx?tree=_4, Stand: 05.04.2015)

\section{$\mathbf{B} \cdot \mathbf{R} \cdot \mathbf{A} \cdot \mathbf{H} \cdot \mathbf{M} \cdot \mathbf{S}{ }^{\circledR} \mathbf{P C T}-\mathbf{Q}{ }^{\circledR}$}

Rapid semi-quantitative test method

Reference Ranges: $\quad<0.5 \quad$ Chronic inflammatory process and autoimmune disease; viral infections; mild to moderate localised bacterial infections

$0 \cdot 5$ - 2 SIRS; multiple trauma; burns

$>2 \quad$ Severe bacterial infections; sepsis; multiple organ failure

Precision and accuracy: $\quad$ As a semi-quantitative test method, the $\mathrm{B} \cdot \mathrm{R} \cdot \mathrm{A} \cdot \mathrm{H} \cdot \mathrm{M} \cdot \mathrm{S} \circledast \mathrm{P}$ PCT$\mathrm{Q}{ }^{\circledR}$ correlates closely to the $\mathrm{B} \cdot \mathrm{R} \cdot \mathrm{A} \cdot \mathrm{H} \cdot \mathrm{M} \cdot \mathrm{S}{ }^{\circledR} \mathrm{PCT} \mathrm{LIA}{ }^{\circledR}$ with regard to the individual concentration ranges. Due to individual differences in the readings, differences between $B \cdot R \cdot A \cdot H \cdot M \cdot S \bowtie$ $\mathrm{PCT}-\mathrm{Q}{ }^{\circledR}$ and $\mathrm{B} \cdot \mathrm{R} \cdot \mathrm{A} \cdot \mathrm{H} \cdot \mathrm{M} \cdot \mathrm{S} \AA \mathrm{PCT} \mathrm{LIA} \AA$ are possible, particularly in the proximity of the PCT concentrations symbolised by the reference band.

Functional Sensitivity: $\quad$ PCT-Q ${ }^{\circledR}$ test has a sensitivity of $0.5 \mathrm{ng} / \mathrm{ml}$ and can therefore only be used for diagnosis of invasive bacterial infection, not for localised infections like infections of the lower respiratory tract.

\section{$\mathbf{B} \cdot \mathbf{R} \cdot \mathbf{A} \cdot \mathbf{H} \cdot \mathbf{M} \cdot \mathbf{S} \circledast$ PCT LIA $®$}

Quantitative manual PCT-Assay

Measuring Range: $\quad$ Concentrations between $0 \cdot 1$ and $500 \mathrm{ng} / \mathrm{ml}$

Precision: $\quad \mathrm{B} \cdot \mathrm{R} \cdot \mathrm{A} \cdot \mathrm{H} \cdot \mathrm{M} \cdot \mathrm{S} \AA \mathrm{PCT}$ LIA ${ }^{\circledR}$ shows a high precision in the determination of serum/plasma PCT concentrations. The intraassay $\mathrm{CV}$ and the inter-assay $\mathrm{CV}$ are $6-10 \%$ in the clinically relevant $\mathrm{PCT}$ concentration range.

Analytical Sensitivity: The detection limit calculated using the imprecision profile has been assessed as being $0.08 \mathrm{ng} / \mathrm{ml}$.

Functional Sensitivity: The functional sensitivity (defined as the lowest analyte concentration that can be determined with an inter-assay $\mathrm{CV}$ $<20$ ) has been assessed as being $0 \cdot 3 \mathrm{ng} / \mathrm{ml}$ with a probability of 95\%. 


\section{$\mathbf{B} \cdot \mathbf{R} \cdot \mathbf{A} \cdot \mathbf{H} \cdot \mathbf{M} \cdot \mathbf{S}{ }^{\circledR}$ PCT sensitive Kryptor ${ }^{\circledR}$}

Fully automated, sensitive, quantitative PCT-Assay

Measuring Range:

Concentrations between 0.02 and $5000 \mathrm{ng} / \mathrm{ml}(0.02$ to $50 \mathrm{ng} / \mathrm{ml}$ directly and up to $5000 \mathrm{ng} / \mathrm{ml}$ after sample dilution)

Precision:

$\mathrm{B} \cdot \mathrm{R} \cdot \mathrm{A} \cdot \mathrm{H} \cdot \mathrm{M} \cdot \mathrm{S}{ }^{\circledR} \mathrm{PCT}$ sensitive Kryptor ${ }^{\circledR}$ shows a high precision in the determination of serum/plasma PCT concentrations. The intra-assay $\mathrm{CV}$ and the inter-assay $\mathrm{CV}$ are $2-3 \%$ on the whole PCT concentration range.

Analytical Sensitivity: The detection limit calculated using the imprecision profile has been assessed as being $0 \cdot 019 \mathrm{ng} / \mathrm{ml}$ with a probability of $95 \%$.

Functional Sensitivity: The functional assay sensitivity (defined as the lowest analyte concentration that can be determined with an inter-assay $\mathrm{CV}$ $<20$ ) has been assessed as being $0.06 \mathrm{ng} / \mathrm{ml}$ with a probability of $95 \%$. 


\section{Appendix 2: QUADAS Items and guidelines for scoring}

1. Was the spectrum of patients representative of the patients who will receive the test in practice? (Patient spectrum)

To be scored "yes", the investigators had to include critically ill patients with probable infection and the patients spectrum should not include a too narrow range concerning age and site of infection.

2. Were selection criteria clearly described? (Selection criteria)

To be scored "yes", the investigators had to report at least inclusion and exclusion criteria.

3. Is the reference standard likely to correctly classify the target condition? (Reference standard)

To be scored "yes", the infection had to be microbiologically confirmed or at least clinically suspected, as evidenced by one or more of the following: white cells in a normally sterile body fluid; perforated viscus; radiographic evidence of pneumonia in association with the production of purulent sputum; a syndrome associated with a high risk of infection (e.g. ascending cholangitis).

4. Is the period between reference standard and index test short enough to be reasonably sure that the target condition did not change between the two tests? (Disease progression bias)

To be scored "yes", 24 or fewer hours had to lie in between the two tests.

5. Did the whole sample or a random selection of the sample, receive verification using a reference standard? (Partial verification bias)

To be scored "yes", all patients, who received a measurement of PCT went on to receive verification of their disease status using the reference standard.

6. Did patients receive the same reference standard regardless of the index test result? (Differential verification bias)

To be scored "yes", all patients had to receive verification of their disease status using definitions according to the American College of Chest Physicians/Society of Critical Care Medicine Consensus Conference (1992) and the German Sepsis Society (2010).

7. Was the reference standard independent of the index test (i.e. the index test did not form part of the reference standard)? (Incorporation)

To be scored "yes", the proof of infection according to the definitions of the American College of Chest Physicians/Society of Critical Care Medicine Consensus Conference 
(1992) and the German Sepsis Society (2010) had to be independent of the measurement of PCT.

8. Was the execution of the index test described in sufficient detail to permit replication of the test? (Description of the index test)

To be scored "yes", the investigators had to report handling and storage of bloodsamples and the PCT-assay used.

9. Was the execution of the reference standard described in sufficient detail to permit its replication? (Description of the reference standard)

To be scored "yes", the investigators had to report how they proved the presence of infection. They had to report, if they took blood cultures, urine cultures or cultures of other body fluids or made chest radiographs etc. Above all they had to report the proportion of positive blood cultures and isolated microorganisms.

10. Were the index test results interpreted without knowledge of the results of the reference standard? (Test review bias)

To be scored "yes", the investigators had to interpret the results of the PCT-test without knowledge of the results of the classification according to the definitions of the American College of Chest Physicians/Society of Critical Care Medicine Consensus Conference (1992) and the German Sepsis Society (2010).

11. Were the reference standard results interpreted without knowledge of the results of the index test? (Diagnostic review bias)

To be scored "yes", the investigators had to classify patient's status acoording to the definitions of the American College of Chest Physicians/Society of Critical Care Medicine Consensus Conference (1992) and the German Sepsis Society (2010) without knowledge of the results of the PCT-test.

12. Were the same clinical data available when test results were interpreted as would be available when the test is used in practice? (Clinical data)

We omitted item 12 of the QUADAS tool because the index test is fully automated and there are no further clinical data needed to interpret the test results.

13. Were uninterpretable or intermediate test results reported? (Uninterpretable results)

To be scored "yes", the investigators had to report any uninterpretable or intermediate result or explicitly state that there are no uninterpretable results.

14. Were withdrawals from the study explained? (Withdrawals)

To be scored "yes", the investigators had to clearly report what happened to all patients who were included to the study; for example, by reporting a flow diagram of study participants or explicitly stating what happened to withdrawals. 


\section{Appendix 3: Methodological quality summary}

Reviewer judgment of methodological quality of included studies, according to the Quality Assessment of Diagnostic Accuracy Studies (QUADAS) tool(Whiting et al. 2003)

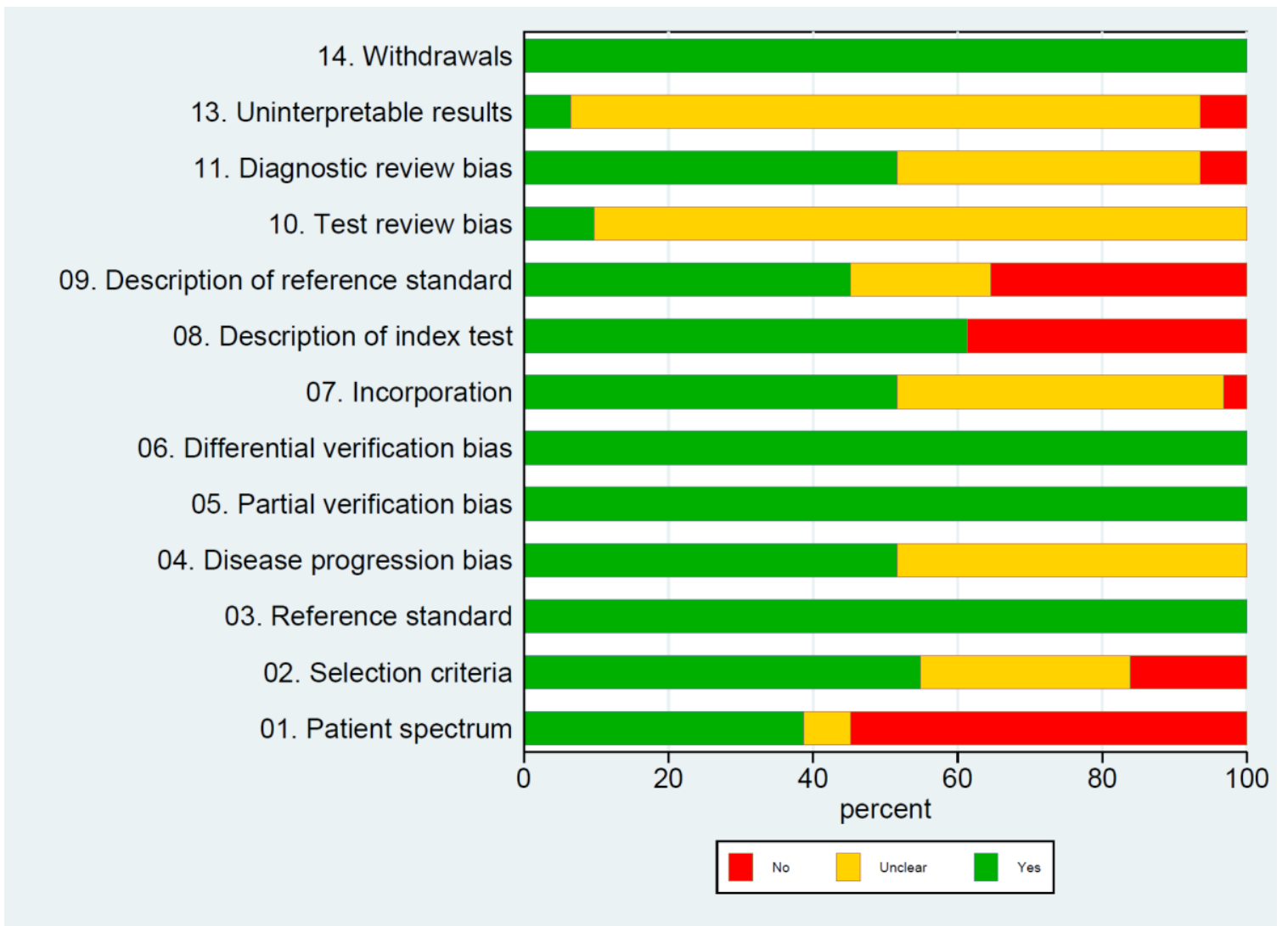




\section{Appendix 4: Methodological quality graph}

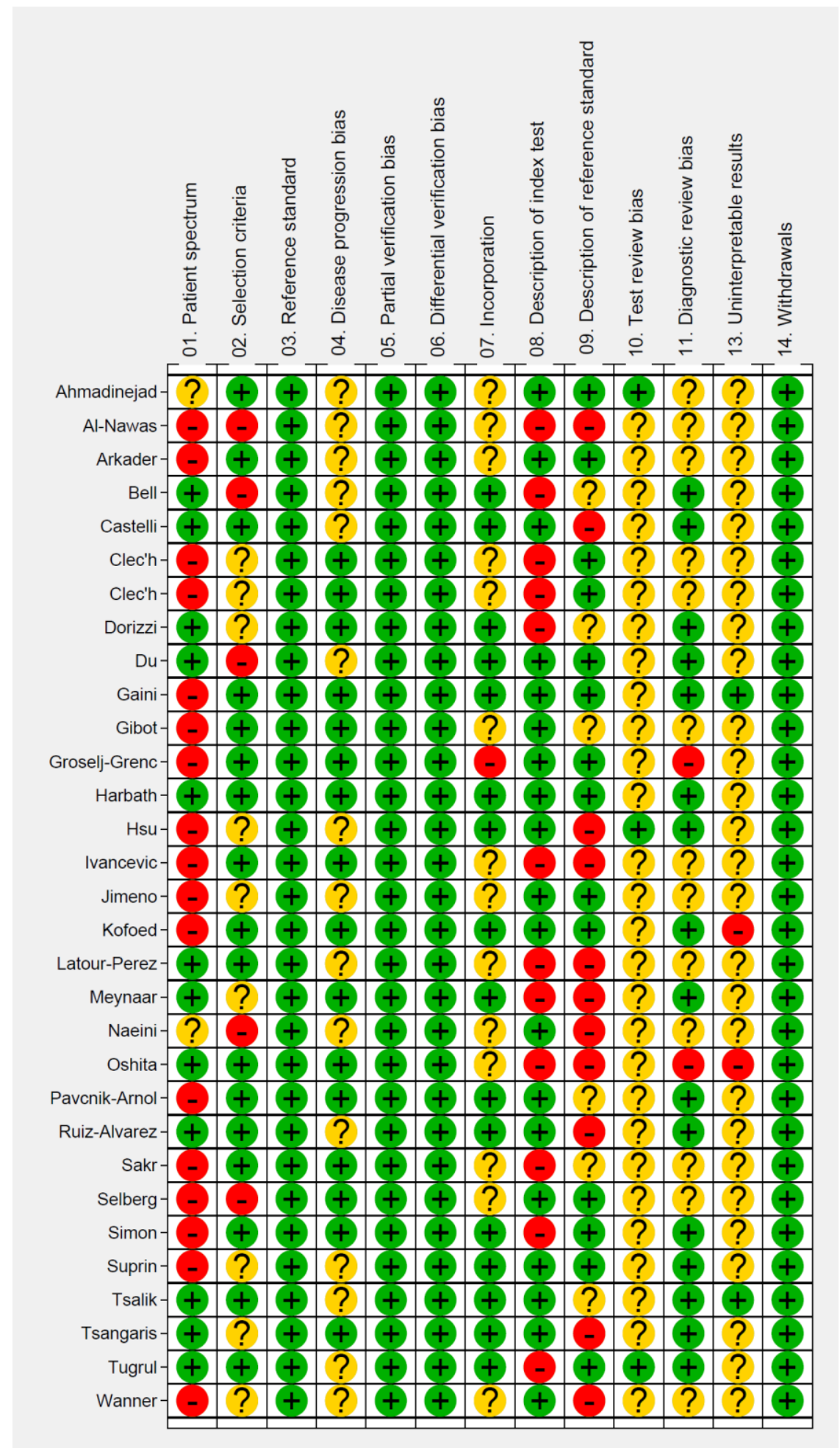


Appendix 5: STARD checklist for reporting of studies of diagnostic accuracy

(Version Januar 2003, http://www.stard-statement.org/, Stand: 05.04.2015)

\begin{tabular}{|c|c|c|}
\hline Section and Topic & $\begin{array}{c}\text { Item } \\
\#\end{array}$ & \\
\hline $\begin{array}{l}\text { TITLE/ABSTRACT/ } \\
\text { KEYWORDS }\end{array}$ & 1 & $\begin{array}{l}\text { Identify the article as a study of diagnostic accuracy } \\
\text { (recommend MeSH heading 'sensitivity and specificity'). }\end{array}$ \\
\hline INTRODUCTION & 2 & $\begin{array}{l}\text { State the research questions or study aims, such as estimating } \\
\text { diagnostic accuracy or comparing accuracy between tests or } \\
\text { across participant groups. }\end{array}$ \\
\hline \multicolumn{3}{|l|}{ METHODS } \\
\hline \multirow[t]{4}{*}{ Participants } & 3 & $\begin{array}{l}\text { The study population: The inclusion and exclusion criteria, } \\
\text { setting and locations where data were collected. }\end{array}$ \\
\hline & 4 & $\begin{array}{l}\text { Participant recruitment: Was recruitment based on presenting } \\
\text { symptoms, results from previous tests, or the fact that the } \\
\text { participants had received the index tests or the reference } \\
\text { standard? }\end{array}$ \\
\hline & 5 & $\begin{array}{l}\text { Participant sampling: Was the study population a consecutive } \\
\text { series of participants defined by the selection criteria in item } 3 \\
\text { and } 4 \text { ? If not, specify how participants were further selected. }\end{array}$ \\
\hline & 6 & $\begin{array}{l}\text { Data collection: Was data collection planned before the index } \\
\text { test and reference standard were performed (prospective study) } \\
\text { or after (retrospective study)? }\end{array}$ \\
\hline \multirow[t]{5}{*}{ Test methods } & 7 & The reference standard and its rationale. \\
\hline & 8 & $\begin{array}{l}\text { Technical specifications of material and methods involved } \\
\text { including how and when measurements were taken, and/or cite } \\
\text { references for index tests and reference standard. }\end{array}$ \\
\hline & 9 & $\begin{array}{l}\text { Definition of and rationale for the units, cut-offs and/or } \\
\text { categories of the results of the index tests and the reference } \\
\text { standard. }\end{array}$ \\
\hline & 10 & $\begin{array}{l}\text { The number, training and expertise of the persons executing } \\
\text { and reading the index tests and the reference standard. }\end{array}$ \\
\hline & 11 & $\begin{array}{l}\text { Whether or not the readers of the index tests and reference } \\
\text { standard were blind (masked) to the results of the other test and } \\
\text { describe any other clinical information available to the readers. }\end{array}$ \\
\hline \multirow[t]{2}{*}{ Statistical methods } & 12 & $\begin{array}{l}\text { Methods for calculating or comparing measures of diagnostic } \\
\text { accuracy, and the statistical methods used to quantify } \\
\text { uncertainty (e.g. } 95 \% \text { confidence intervals). }\end{array}$ \\
\hline & 13 & Methods for calculating test reproducibility, if done. \\
\hline \multicolumn{3}{|l|}{ RESULTS } \\
\hline Participants & 14 & $\begin{array}{l}\text { When study was performed, including beginning and end dates } \\
\text { of recruitment. }\end{array}$ \\
\hline
\end{tabular}




\begin{tabular}{|c|c|c|}
\hline & 15 & $\begin{array}{l}\text { Clinical and demographic characteristics of the study } \\
\text { population (at least information on age, gender, spectrum of } \\
\text { presenting symptoms). }\end{array}$ \\
\hline & 16 & $\begin{array}{l}\text { The number of participants satisfying the criteria for inclusion } \\
\text { who did or did not undergo the index tests and/or the reference } \\
\text { standard; describe why participants failed to undergo either test } \\
\text { (a flow diagram is strongly recommended). }\end{array}$ \\
\hline \multirow[t]{4}{*}{ Test results } & 17 & $\begin{array}{l}\text { Time-interval between the index tests and the reference } \\
\text { standard, and any treatment administered in between. }\end{array}$ \\
\hline & 18 & $\begin{array}{l}\text { Distribution of severity of disease (define criteria) in those with } \\
\text { the target condition; other diagnoses in participants without the } \\
\text { target condition. }\end{array}$ \\
\hline & 19 & $\begin{array}{l}\text { A cross tabulation of the results of the index tests (including } \\
\text { indeterminate and missing results) by the results of the } \\
\text { reference standard; for continuous results, the distribution of } \\
\text { the test results by the results of the reference standard. }\end{array}$ \\
\hline & 20 & $\begin{array}{l}\text { Any adverse events from performing the index tests or the } \\
\text { reference standard. }\end{array}$ \\
\hline \multirow[t]{4}{*}{ Estimates } & 21 & $\begin{array}{l}\text { Estimates of diagnostic accuracy and measures of statistical } \\
\text { uncertainty (e.g. } 95 \% \text { confidence intervals). }\end{array}$ \\
\hline & 22 & $\begin{array}{l}\text { How indeterminate results, missing data and outliers of the } \\
\text { index tests were handled. }\end{array}$ \\
\hline & 23 & $\begin{array}{l}\text { Estimates of variability of diagnostic accuracy between } \\
\text { subgroups of participants, readers or centers, if done. }\end{array}$ \\
\hline & 24 & Estimates of test reproducibility, if done. \\
\hline DISCUSSION & 25 & Discuss the clinical applicability of the study findings. \\
\hline
\end{tabular}


Appendix 6: Deeks' Funnel Plot Asymmetry Test

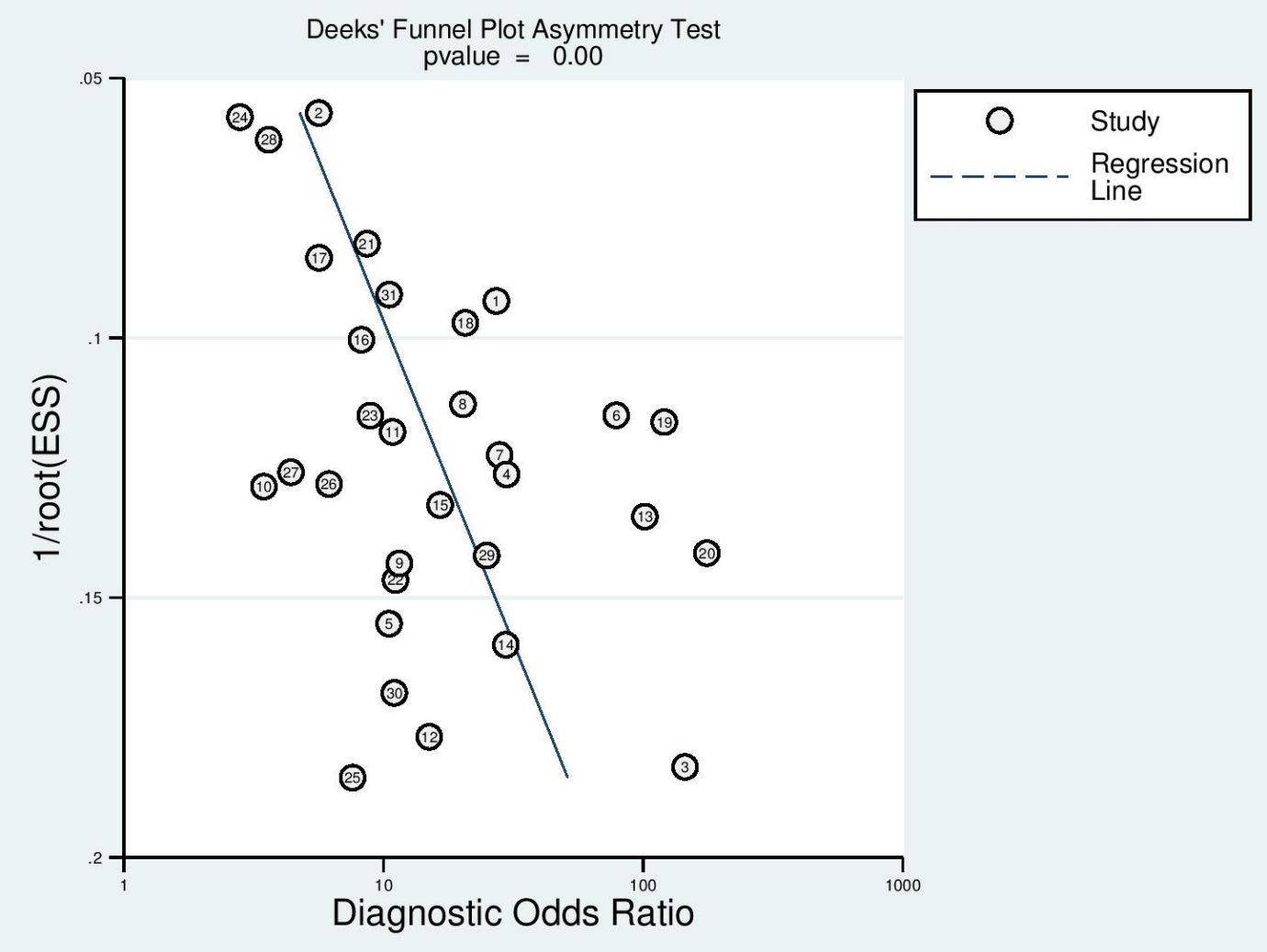




\section{Danksagung}

Nach zahlreichen Stunden der Arbeit liegt nun die endgültige Version meiner Dissertation vor mir. Meinen herzlichsten Dank möchte ich nun einigen Personen aussprechen, ohne die es wohl nicht dazu gekommen wäre.

Mein größter Dank gilt meinem Doktorvater Herrn Prof. Dr. Schlattmann, zum einen für die freundliche Bereitstellung des Promotionsthemas, zum anderen aber auch für seine kompetente und engagierte Betreuung, die Zeit und Aufmerksamkeit, die er sowohl der Publikation als auch der Dissertation widmete und dafür, dass er mich hin und wieder daran erinnerte, „dass der 100-Meter-Läufer auch nicht fünf Meter vor dem Ziel aufgibt.“

Meinem klinischen Betreuer Herrn Prof. Dr. Brunkhorst danke ich ebenfalls für sein Engagement sowie seine kompetente und vielfältige fachliche Betreuung.

Besonderen Dank richte ich an das Center for Sepsis Control and Care (CSCC) für die einjährige Promotionsförderung, die es mir ermöglichte, mich voll und ganz auf meine Arbeit an der Publikation zu konzentrieren.

Des Weiteren bedanke ich mich bei meiner ehemaligen Kommilitonin und Mitstreiterin Anna Prkno für ihre eifrige Mitarbeit an unseren Publikationen sowie die innige Freundschaft während des Studiums.

Darüber hinaus möchte ich mich bei Herrn Dr. Moritz Rau bedanken: Ebenso für seine Freundschaft wie für seine guten Englischkenntnisse, mit welchen er einige kleine sprachliche Korrekturen an meiner Publikation vornahm.

Außerdem möchte ich mich bei meinem Lebensgefährten und besten Freund Florian Vogt für seinen unermüdlichen Beistand und Rückhalt bedanken und dafür, dass er es auch in schwierigen Phasen geschafft hat, mich wieder zum Lachen zu bringen.

Nicht zuletzt bedanke ich mich von Herzen bei meinen Eltern für ihre allseits gegebene Anteilnahme, Unterstützung und Geduld, die mir immer wieder den Rücken stärkte. Ohne sie wäre mir das Medizinstudium niemals möglich gewesen. 


\section{Ehrenwörtliche Erklärung}

Hiermit erkläre ich,

dass mir die Promotionsordnung der Medizinischen Fakultät der Friedrich-SchillerUniversität bekannt ist,

ich die Dissertation selbst angefertigt habe und alle von mir benutzten Hilfsmittel, persönlichen Mitteilungen und Quellen in meiner Arbeit angegeben sind,

mich folgende Personen bei der Auswahl und Auswertung des Materials sowie bei der Herstellung des Manuskripts unterstützt haben: Herr Prof. Dr. P. Schlattmann, Herr Prof. Dr. F.M. Brunkhorst.

die Hilfe eines Promotionsberaters nicht in Anspruch genommen wurde und dass Dritte weder unmittelbar noch mittelbar geldwerte Leistungen von mir für Arbeiten erhalten haben, die in Zusammenhang mit dem Inhalt der vorgelegten Dissertation stehen,

dass ich die Dissertation noch nicht als Prüfungsarbeit für eine staatliche oder andere wissenschaftliche Prüfung eingereicht habe und

dass ich die gleiche, eine in wesentlichen Teilen ähnliche oder eine andere Abhandlung nicht bei einer anderen Hochschule als Dissertation eingereicht habe.

Gotha, den

Christina Wacker 